\title{
Original paper \\ Genesis of chromitites from Korydallos, Pindos Ophiolite Complex, Greece, based on spinel chemistry and PGE-mineralogy
}

\author{
Argyrios N. KAPSIOTIS
}

Department of Geology, Section of Earth Materials, Panepistimiopolis of Rion, University of Patras, 26504 Patras, Greece; kapsiotisa@yahoo.gr

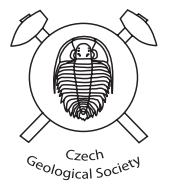

The Pindos Ophiolite Complex, located in northwestern Greece, hosts various chromite deposits of both metallurgical (high-Cr) and refractory (high-Al) type. In Korydallos are encountered both types of chromitites. These are podiform chromitites that have small dimensions and occur sub-concordantly to the hosting peridotites. The Cr-rich chromitites contain magnesiochromite with high $\mathrm{Cr} \#[\mathrm{Cr} /(\mathrm{Cr}+\mathrm{Al})$ : $0.65-0.68]$ and low platinum-group element (PGE) contents (294.1 ppb), whereas the Al-rich ones host spinel with low Cr\# (0.44-0.48) and elevated total PGE grades (28830 ppb). The former display a nearly flat C1-normalized PGE-pattern, whereas the latter show a positively sloped normalized PGE-pattern. The in situ mineralogical investigation of the Cr-rich chromitites revealed a platinum-group mineral (PGM) assemblage dominated by small $(\leq 3 \mu \mathrm{m})$ sperrylite, laurite and erlichmanite grains (determined by recalculated qualitative analytical data). Textural relations suggest crystallization under conditions of high $f S_{2}$ and $f A s$ and/or low $T$. The in concentrates mineralogical study of the Al-rich chromitites showed that the PGM assemblage that they host is dominated by $\mathrm{Pd}-\mathrm{Cu}$ and $\mathrm{Pd}-\mathrm{Au}-\mathrm{Cu}$ alloys. The vast majority of these alloys is associated with abundant secondary BMS (base-metal sulfides) and BMA (base-metal alloys), thus confirming that a sulfide melt scavenged the PGE $+\mathrm{Au}$ of the silicate magma from which chromian spinel had already started to crystallize. Both assemblages were affected by an invasion of an oxidizing aqueous fluid in the investigated chromitites. Combined data indicate that the chromitites from the Korydallos area crystallized from a progressively differentiating MORB/IAT melt, produced in a small backarc basin in a supra-subduction zone setting.

Keywords: platinum-group minerals (PGM), chromitites, ophiolites, Pindos, Greece

Received: 29 November, 2012; accepted: 2 April 2013; handling editor: R. Skála

\section{Introduction}

Chromitites commonly occur in the form of small pods in the mantle suite of ophiolite complexes. Frequently high$\mathrm{Cr}$ and high-Al chromitites are found to coexist within a single ultramafic massif containing variably depleted peridotites (e.g., Leblanc 1995; Economou-Eliopoulos 1996; Melcher et al. 1997; Proenza et al. 1999; Gervilla et al. 2005).

These ores are important because they represent a natural source of chromium (Cr) and, to a lesser degree, of platinum-group elements (PGE). Podiform chromitites are commonly enriched in the most compatible PGE frequently referred as IPGE (Iridium-subgroup of PGE: Os, Ir and $\mathrm{Ru}$ ) with respect to the more incompatible ones, commonly referred as PPGE (Pt-subgroup of PGE: Rh, $\mathrm{Pt}$ and Pd) (Barnes et al. 1985). However, various cases of podiform chromite ores showing a significant enrichment in PPGE have been pointed out worldwide (e.g., Bacuta et al. 1990; Ohnenstetter et al. 1991; Melcher et al. 1999; Malitch et al. 2001; Proenza et al. 2001; Burgath et al. 2003; Escayola et al. 2011). Predominance of PPGE in these chromitites is indicative of the presence of PPGE-based mineral species. In particular, PPGM crystallization is controlled by the concentration of sulfur in the magma (e.g., Cawthorn 1999; Godel et al. 2007). When sulfur saturation is achieved, the bulk PGE content is scavenged by the sulfide melt (e.g., Fleet et al. 1993; $\mathrm{Li}$ et al. 1996), thus leading to the formation of PPGM texturally related with base-metal sulfides (BMS). Except for magmatic processes, hydrothermal alteration can also enrich a chromitite body in PPGE (e.g., Malitch et al. 2001). Specifically, $\mathrm{Cl}^{-}$rich fluids can cause extensive redistribution and deposition of the most mobile PPGE (especially Pt and Pd, Naldrett 1981; Wood 2002; Piña et al. 2008; Wood and Normand 2008) in the form of secondary PPGM.

This paper presents new data on the composition of chromian spinel from Korydallos chromitites, and discusses the critical information they carry about the genetic processes involved in their formation. Moreover, a combined in situ and in concentrates mineralogical study is applied to unravel the differences of PGE-mineralization between the examined chromitites and compare the PGM data with those obtained by previous studies on Korydallos chromitites. 

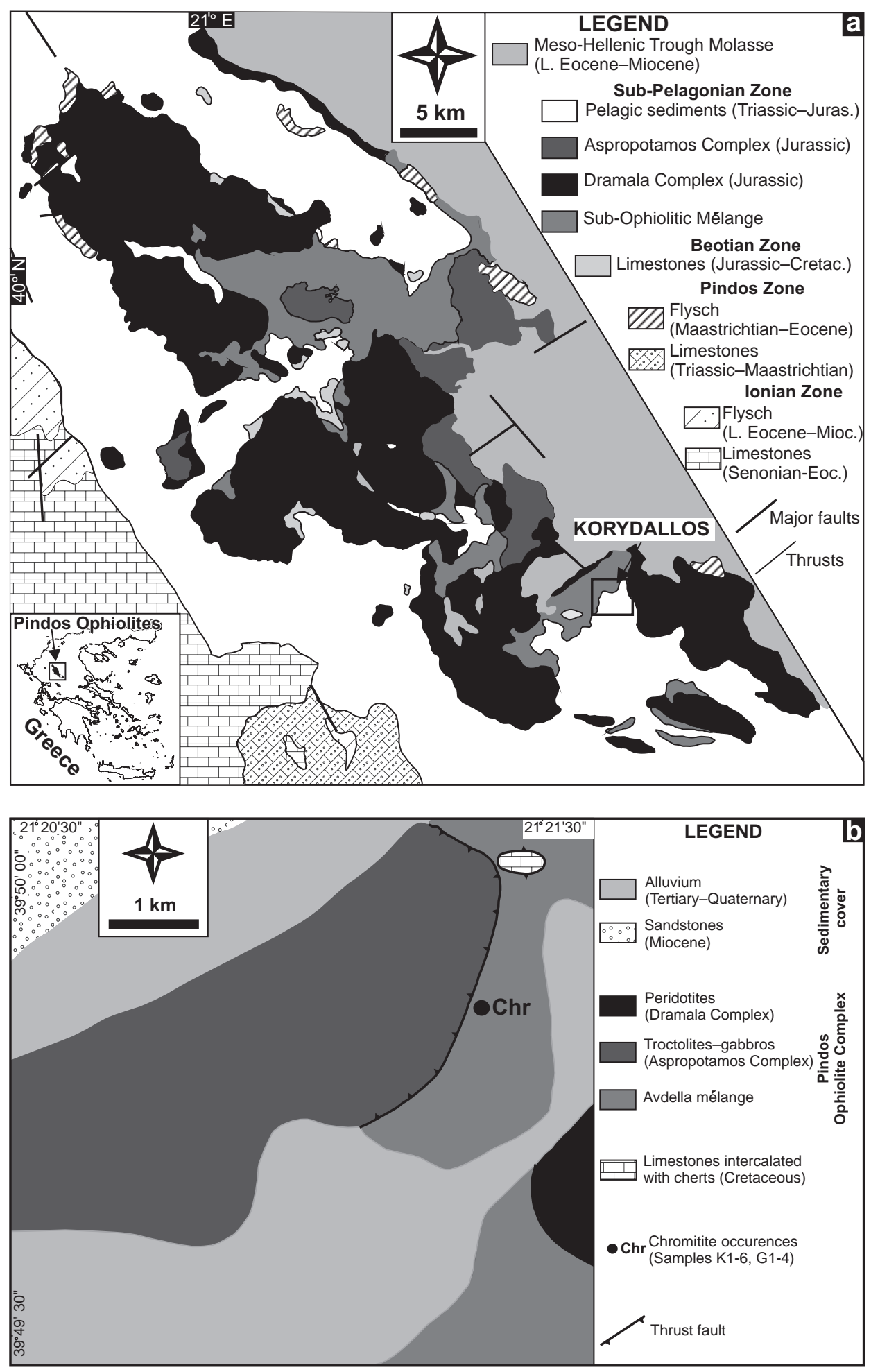

Fig. 1a - Simplified geological map of the Pindos Ophiolite Complex showing the location of the Korydallos area (modified after Kostopoulos 1989; Jones and Robertson 1991) and inset map illustrating the location of the Pindos ophiolites in the Greek Peninsula. b - Detailed geological map of the Korydallos area showing the location from which the studied chromitite samples were collected.

\section{Previous work on composition and PGM of chromitites from Korydallos}

During the last two decades several studies concerning chromian spinel composition, PGE-geochemistry and PGE-mineralogy were carried out in order to explain the genesis of Korydallos chromitites (Economou-Eliopoulos and Vacondios 1995; Tarkian et al. 1996; EconomouEliopoulos et al. 1999; Prichard et al. 2008a; Kapsiotis et al. 2010). The first studies indicated that Korydallos chromitites show remarkable compositional differences compared to other chromitite deposits from the Pindos 
Massif (e.g., Milia, Pefki), being composed of low-Cr\# $[\mathrm{Cr} /(\mathrm{Cr}+\mathrm{Al})]$ chromian spinel (commonly $<0.60)$. The bulk-rock analyses showed that they tend to be rich in $\mathrm{Pt}$ and Pd and display positively sloped chondrite-normalized PGE patterns.

The first study on the PGM content of Korydallos chromitites was carried out by Tarkian et al. (1996). The PGM data were obtained using the traditionally applied method of the in situ mineralogical investigation. Their research revealed a PGM assemblage dominated by laurite (2 grains), sperrylite ( 2 grains) and an unidentified phase corresponding to the chemical formula $\mathrm{Pt}(\mathrm{Ni}, \mathrm{Fe})_{3}$ (4 grains in 10 polished sections). Based on textural data, the authors claimed that laurite represented a magmatic phase, whereas the other PGM were secondary in origin.

Prichard et al. (2008a) also studied in situ the same Korydallos chromitite samples previously investigated by Tarkian et al. (1996). The authors described a more representative PGM assemblage mainly dominated by a Pt-Ni-Fe alloy (over 50 grains), accompanied by a $\mathrm{Pd}-\mathrm{Pt}-\mathrm{Cu}$-rich alloy (over 30 grains), Pt arsenides, (most likely sperrylite, 9 grains), Rh-Ir-Pt sulfarsenides, laurite, Os-Ir-Ru alloys, Os- $\mathrm{Ru}-\mathrm{Pt}$ alloys, $\mathrm{Pt}-\mathrm{Rh}$ alloys, $\mathrm{Pt}-\mathrm{Cu}$ alloys, Pd-bearing Ni-Fe alloys, Pd-Pt-bearing $\mathrm{Cu}$ alloys and Pd-bearing oxy-hydroxides. They also noticed the association of Pt- and Pd-bearing minerals with base metal (BM) enriched minerals, which indicates that Pt and Pd were collected by small quantities of an immiscible sulfide liquid. Moreover, they claimed that Pt- and Pd-bearing BM alloys and sulfarsenides were formed by loss of sulfur during serpentinization. According to them, a further stage of alteration produced Pd-bearing oxy-hydroxides.

Recently Kapsiotis et al. (2010) studied PGM concentrates from the high-PGE grade high-Al chromitites of Korydallos. That research revealed a PGM assemblage dominated by the following phases (in decreasing order of abundance): $\mathrm{Pd}-\mathrm{Cu}$ alloys, Pd-bearing tetra-auricupride, nielsenite, sperrylite, skaergaardite, Pd-bearing auricupride, Pt and Pd oxides, accompanied by minor Pt$\mathrm{Fe}-\mathrm{Ni}$ alloys, hollingworthite, $\mathrm{Pt}-\mathrm{Cu}$ alloys, isomertieite, zvyagintsevite, native $\mathrm{Au}$, keithconnite, naldrettite and Rh-bearing bismuthotelluride. The vast majority of the recovered PPGM was found to be associated with BMS and base-metal alloys (BMA), thus confirming that a sulfide melt scavenged the noble metal content of the chromite-forming magma.

\section{Regional geology and sampling}

The Pindos Ophiolite Complex is located in northwestern Greece and corresponds to a piece of Middle to Upper Jurassic oceanic crust (Rassios and Smith 2000) (Fig. 1a). It was tectonically emplaced over the autochthonous Maastrichtian-Eocene Pindos flysch. It can be subdivided into four principal tectonic units: the Dramala Complex, the Loumnitsa Unit and the Aspropotamos Complex, all structurally overlying a sub-ophiolitic chaotic lithological formation known as the Avdella Mélange (Jones and Robertson 1991). The Dramala Unit comprises variably depleted harzburgite-dunite masses $\left(>1000 \mathrm{~km}^{2}\right)$, which may host small chromitite bodies of massive, disseminated, schlieren and, less commonly, nodular texture. The crustal rocks of the Aspropotamos Complex cover a wide range of geochemical affinities, varying from $\mathrm{N}$ MORB through MORB/IAT to IAT and boninites cross cutting all the previous types of volcanics (Kostopoulos 1989; Pe-Piper et al. 2004). The Loumnitsa Unit represents the metamorphic sole of both Dramala and Aspropotamos complexes, consisting of low amphibolite- and greenschist-facies metaigneous and metasedimentary rocks that have yielded amphibole Ar-Ar ages of $169 \pm$ 5 and $165 \pm 3 \mathrm{Ma}$ (Whitechurch and Parrot 1978; Spray and Roddick 1980).

Ten representative chromitite samples were collected from the same peridotite block found in a chaotic lithological mixture of mélange type in the southeastern part of the complex (Fig. 1b). Mélange consists of rock slices that are set in a strongly deformed yellowish to dark green colored, clay to muddy matrix. Different varieties of blocks can be identified in Korydallos Mélange, the most representative are: i) Pelagic limestones of Late Triassic and Upper Cretaceous age, ii) cherts, iii) siliciclastic turbidites, iv) volcanic rocks (mainly pillow-lava basalts and dolerites, Fig. 2a), and finally, v) plutonic rocks (serpentinites after dunites, serpentinized harzburgites and troctolites). The mélange matrix is composed of pebbles that are also of sedimentary, volcanic or plutonic origin. One peridotite block was found to host a few chromitite pods. It is small (up to a few tens of $\mathrm{m}$ long) and red colored due to severe weathering. Moreover it is intensively mylonitized, serpentinized and sheared.

\section{Geological and petrographic descrip- tion of the chromitites}

The studied chromitites have small dimensions (less than a few $\mathrm{m}$ long and tens of $\mathrm{cm}$ thick), are mostly podiform, and occur sub-concordantly to the foliation of the host peridotite (serpentinite after dunite). Some chromitites display gradational contacts with the host rock. They are thin to medium grained and massive (>70 vol. \% of chromian spinel) to densely disseminated (50-70 vol. \% of chromian spinel) in texture.

They are fractured and locally show a cataclastic texture (Fig. 2b). Their interstitial silicate matrix con- 

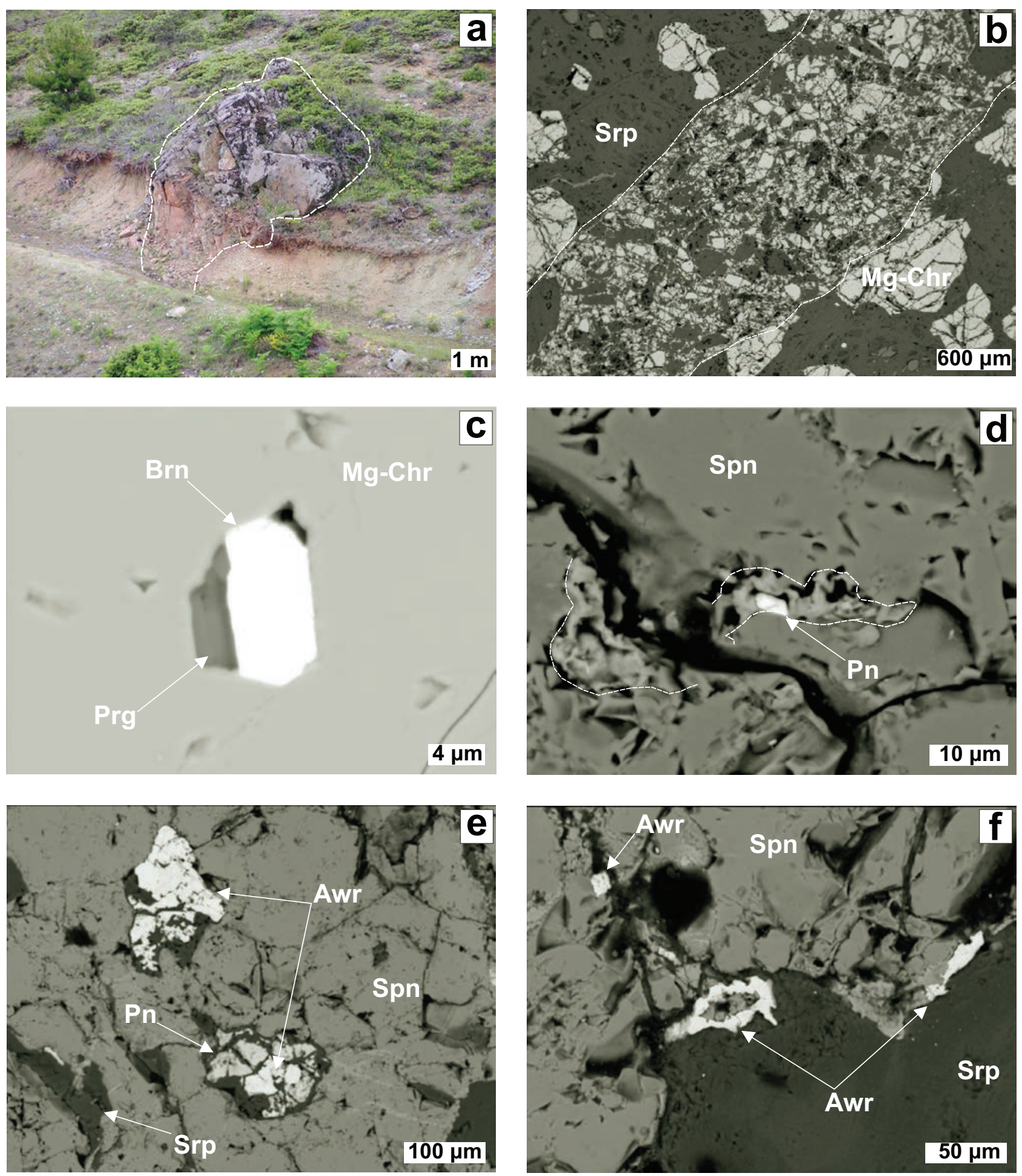

Fig. 2a - Exotic dolerite block (noted by the thick dashed line) in the Korydallos Mélange; b-f Back-scattered-electron (BSE) images showing micro-textural characteristics of the studied chromitites: a - the fractured nature of the investigated chromitites; $\mathbf{c}$ - a composite inclusion of pargasite and bornite in magnesiochromite; $\mathbf{d}$-a pentlandite inclusion in ferrian chromite (noted by the thick dashed line); $\mathbf{e}-\mathrm{a}$ composite inclusion of BMS and BMA in spinel; $\mathbf{f}$ - awaruite grains attached to spinel. Abbreviations: Awr - awaruite, Brn - bornite, Mg-Chr - magnesiochromite, Prg - Pargasite, Pn - pentlandite, Srp - serpentine, Spn - spinel. 
sists of serpentine accompanied by minor clinochlore, tremolite and talc. Serpentine displays mesh and less frequently interpenetrating texture. Only relics of primary olivine are preserved in some samples. Silicate phases that occur as inclusions in the chromian spinel are serpentine, chlorite, olivine and pargasite (Fig. 2c). Typically monomineralic silicate inclusions predominate. Chromian spinel is commonly altered to ferrian chromite along fractures (Fig. 2d). Ferrian chromite rims can be up to $250 \mu \mathrm{m}$ thick and are always surrounded by chromian clinochlore.

A large number of BMS and BMA was found in some of the investigated chromitites in a variety of textures: i) as inclusions in chromian spinel or ferrian chromite rims (Fig. 2d-e), ii) in the interstitial altered silicate matrix, iii) attached to chromian spinel grains (Fig. 2f) and iv) along cracks in chromian spinel. Awaruite and pentlandite (commonly enriched in Co) are the dominant BM minerals species found in the Korydallos chromitites, followed by millerite and minor orcelite, native $\mathrm{Ni}$ and bornite. The BMS and BMA grains are up to $500 \mu \mathrm{m}$ in size and sometimes can be distinguishable even in hand specimen. They occur both as single and composite grains; the latter are made of pentlandite-awaruite, awaruite-orcelite or millerite-awaruite.

\section{Analytical methods}

All the studied samples were collected within a radius of a few meters. Each was taken from different but neighboring chromitite pods. One polished section was prepared for each sample. Petrographic and mineralogical work was carried out on 10 polished thin sections by both optical (250-800× magnifications) and electron microscopy, and electron-microprobe analysis. In six of them generally small $(\leq 3 \mu \mathrm{m})$ PGM grains were discovered. The PGM were investigated in situ and imaged using a Super JEOL JSM-6300 Scanning Electron Microscope (SEM) at the University of Patras, with an accelerating voltage of $20-30 \mathrm{kV}$ and a beam current of 2-10 nA. Qualitative analyses of the PGM were carried out by Energy-Dispersive Spectrometry (EDS).

Quantitative analyses of the chromian spinel were performed at the Department of Earth Sciences, McGill University, Canada, using a JXA JEOL-8900L electron microprobe operated in Wavelength-Dispersive Spectrometry (WDS) mode at an acceleration voltage of $15 \mathrm{kV}$ and a beam current of $20 \mathrm{nA}$, with a beam diameter of about $5 \mu \mathrm{m}$. The total counting time was $20 \mathrm{~s}$. The ZAF correction software was put into use (Reimer 1998). Calibrations were done using natural

Tab. 1 Representative electron-microprobe analyses of magnesiochromite from Korydallos Cr-rich chromitites

\begin{tabular}{|c|c|c|c|c|c|c|c|c|c|}
\hline Sample & $\mathrm{K}-1$ & $\mathrm{~K}-1$ & $\mathrm{~K}-1$ & $\mathrm{~K}-2$ & $\mathrm{~K}-2$ & $\mathrm{~K}-3$ & $\mathrm{~K}-4$ & K-6 & K-6 \\
\hline Analysis (wt. \%) & 14 & 15 & 16 & 17 & 18 & 19 & 21 & 22 & 23 \\
\hline $\mathrm{SiO}_{2}$ & - & - & - & - & - & - & - & - & - \\
\hline $\mathrm{TiO}_{2}$ & 0.03 & 0.17 & 0.05 & 0.34 & 0.20 & 0.08 & 0.27 & 0.30 & 0.29 \\
\hline $\mathrm{Al}_{2} \mathrm{O}_{3}$ & 17.64 & 17.92 & 19.30 & 16.79 & 16.95 & 16.98 & 17.08 & 18.02 & 16.64 \\
\hline $\mathrm{Cr}_{2} \mathrm{O}_{3}$ & 52.33 & 51.99 & 53.35 & 51.79 & 52.09 & 53.30 & 52.64 & 50.77 & 52.40 \\
\hline $\mathrm{Fe}_{2} \mathrm{O}_{3}$ & 1.12 & 0.89 & - & 2.03 & 2.52 & 1.53 & 1.98 & 2.12 & 1.77 \\
\hline $\mathrm{FeO}$ & 16.10 & 15.86 & 16.54 & 15.50 & 15.16 & 14.89 & 15.82 & 16.95 & 15.76 \\
\hline $\mathrm{MnO}$ & - & 0.40 & - & 1.11 & 0.36 & - & - & 1.21 & - \\
\hline $\mathrm{MgO}$ & 12.13 & 12.14 & 12.15 & 11.90 & 12.64 & 12.96 & 12.61 & 11.28 & 12.37 \\
\hline $\mathrm{NiO}$ & - & - & - & - & - & - & - & - & - \\
\hline Total & 99.35 & 99.37 & 101.39 & 99.45 & 99.92 & 99.73 & 100.40 & 100.65 & 99.23 \\
\hline \multicolumn{10}{|c|}{ Cations calculated on the basis of 32 atoms of $\mathrm{O}$} \\
\hline $\mathrm{Si}$ & - & - & - & - & - & - & - & - & - \\
\hline Al & 5.272 & 5.347 & 5.620 & 5.040 & 5.041 & 5.045 & 5.057 & 5.350 & 4.992 \\
\hline $\mathrm{Cr}$ & 10.487 & 10.403 & 10.418 & 10.425 & 10.389 & 10.619 & 10.451 & 10.108 & 10.452 \\
\hline $\mathrm{Fe}^{3+}$ & 0.214 & 0.169 & - & 0.388 & 0.478 & 0.289 & 0.375 & 0.403 & 0.338 \\
\hline $\mathrm{Ti}$ & 0.006 & 0.032 & 0.009 & 0.065 & 0.038 & 0.015 & 0.051 & 0.057 & 0.056 \\
\hline $\mathrm{Mg}$ & 4.589 & 4.586 & 4.479 & 4.522 & 4.759 & 4.874 & 4.726 & 4.239 & 4.698 \\
\hline $\mathrm{Fe}^{2+}$ & 3.417 & 3.361 & 3.420 & 3.304 & 3.202 & 3.141 & 3.325 & 3.574 & 3.358 \\
\hline $\mathrm{Mn}$ & - & 0.086 & - & 0.240 & 0.077 & - & - & 0.258 & - \\
\hline $\mathrm{Ni}$ & - & - & - & - & - & - & - & - & - \\
\hline$\Sigma$ & 23.985 & 23.984 & 23.946 & 23.984 & 23.984 & 23.983 & 23.985 & 23.989 & 23.984 \\
\hline $\mathrm{Cr} \#$ & 0.67 & 0.66 & 0.65 & 0.67 & 0.67 & 0.68 & 0.67 & 0.65 & 0.68 \\
\hline Mg\# & 0.57 & 0.58 & 0.57 & 0.58 & 0.60 & 0.61 & 0.59 & 0.54 & 0.58 \\
\hline
\end{tabular}

- not detected 
Tab. 2 Representative electron-microprobe analyses of spinel from Korydallos Al-rich chromitites

\begin{tabular}{|c|c|c|c|c|c|c|c|c|c|}
\hline Sample & G-1 & G-2 & G-2 & G-3 & G-3 & G-3 & G-4 & G-4 & G-4 \\
\hline Analysis (wt. \%) & 1 & 3 & 4 & 5 & 6 & 10 & 11 & 12 & 13 \\
\hline $\mathrm{SiO}_{2}$ & - & - & - & - & - & - & - & - & 0.09 \\
\hline $\mathrm{TiO}_{2}$ & 0.17 & 0.14 & 0.20 & 0.17 & 0.29 & 0.29 & 0.18 & 0.02 & 0.04 \\
\hline $\mathrm{Al}_{2} \mathrm{O}_{3}$ & 31.85 & 31.37 & 30.34 & 29.69 & 30.22 & 31.70 & 32.03 & 29.49 & 30.89 \\
\hline $\mathrm{Cr}_{2} \mathrm{O}_{3}$ & 37.58 & 38.92 & 38.39 & 38.81 & 39.96 & 38.13 & 37.24 & 39.99 & 38.23 \\
\hline $\mathrm{Fe}_{2} \mathrm{O}_{3}$ & - & 0.54 & 0.39 & 1.30 & 0.19 & 0.90 & 1.06 & 1.72 & 1.43 \\
\hline $\mathrm{FeO}$ & 15.55 & 14.84 & 16.62 & 16.04 & 16.30 & 14.78 & 16.70 & 16.18 & 16.72 \\
\hline $\mathrm{MnO}$ & 0.54 & - & - & 0.51 & - & 0.02 & - & - & - \\
\hline $\mathrm{MgO}$ & 13.57 & 14.67 & 13.15 & 13.24 & 13.74 & 14.86 & 13.88 & 13.64 & 13.49 \\
\hline $\mathrm{NiO}$ & 0.10 & 0.38 & 0.21 & - & - & 0.24 & - & - & - \\
\hline Total & 99.36 & 100.86 & 99.30 & 99.43 & 100.70 & 100.92 & 101.09 & 101.03 & 100.88 \\
\hline \multicolumn{10}{|c|}{ Cations calculated on the basis of 32 atoms of $\mathrm{O}$} \\
\hline $\mathrm{Si}$ & - & - & - & - & - & - & - & - & 0.021 \\
\hline $\mathrm{Cr}$ & 7.039 & 7.178 & 7.262 & 7.358 & 7.448 & 7.011 & 6.873 & 7.464 & 7.109 \\
\hline $\mathrm{Fe}^{3+}$ & - & 0.095 & 0.070 & 0.070 & 0.034 & 0.158 & 0.186 & 0.305 & 0.252 \\
\hline $\mathrm{Ti}$ & 0.030 & 0.025 & 0.036 & 0.031 & 0.051 & 0.051 & 0.032 & 0.004 & 0.007 \\
\hline $\mathrm{Mg}$ & 4.799 & 5.107 & 4.696 & 4.739 & 4.834 & 5.158 & 4.836 & 4.806 & 4.736 \\
\hline $\mathrm{Fe}^{2+}$ & 3.085 & 2.899 & 3.329 & 3.337 & 3.217 & 2.877 & 3.264 & 3.197 & 3.292 \\
\hline Mn & 0.108 & - & - & 0.104 & - & 0.004 & - & - & - \\
\hline $\mathrm{Ni}$ & 0.020 & 0.070 & 0.040 & - & - & 0.040 & - & - & - \\
\hline$\Sigma$ & 23.978 & 24.001 & 23.992 & 24.034 & 23.984 & 23.991 & 24.007 & 23.984 & 23.983 \\
\hline $\mathrm{Cr} \#$ & 0.44 & 0.45 & 0.46 & 0.47 & 0.47 & 0.45 & 0.44 & 0.48 & 0.45 \\
\hline Mg\# & 0.61 & 0.64 & 0.59 & 0.59 & 0.60 & 0.64 & 0.60 & 0.60 & 0.59 \\
\hline
\end{tabular}

- not detected

and synthetic reference materials. The proportion of $\mathrm{Fe}^{3+}$ in chromian spinel was calculated based on stoichiometry $\left(\mathrm{AB}_{2} \mathrm{O}_{4}\right)$. Selected analytical results for chromian spinel from the investigated chromitites are listed in Tabs 1-2.

Two samples of chromitites were analyzed for PGE + $\mathrm{Au}$ at the Activation Laboratories Ltd., Ontario, Canada by Instrumental Neutron-Activation Analysis (INAA) after a pre-concentration of PGE + Au with nickel sulfide fire-assay collection. Detection limits were $10 \mathrm{ppb}$ for Os, $0.1 \mathrm{ppb}$ for Ir, $5 \mathrm{ppb}$ for $\mathrm{Ru}$ and $\mathrm{Pt}, 0.2 \mathrm{ppb}$ for $\mathrm{Rh}$, $2 \mathrm{ppb}$ for Pd and $0.5 \mathrm{ppb}$ for Au. Analytical results for PGE are listed in Tab. 3.

The processing and recovery of the PGM were carried out at SGS Canada Inc., Canada. The super-panner technique applied for the recovery of the PGM from the high-Al chromitites is described in detail in Kapsiotis et al. (2010).

Quantitative analyses of the recovered PGM were performed at the Department of Earth and Planetary Sciences, McGill University, Canada, by a JXA JEOL-
8900L electron microprobe operated in WDS mode at an acceleration voltage of $20 \mathrm{kV}$ and a beam current of 30 $\mathrm{nA}$, with a beam diameter of $2-3 \mu \mathrm{m}$. The total counting time (for both background and peak positions) was $20 \mathrm{~s}$. The PRZ correction software was implemented. The $\mathrm{X}$-ray $K_{\alpha}$ lines were used for $\mathrm{S}, \mathrm{As}, \mathrm{Fe}, \mathrm{Ni}, \mathrm{Co}$ and $\mathrm{Cu}$, $L_{\alpha}$ lines for $\mathrm{Ru}, \mathrm{Ir}, \mathrm{Rh}, \mathrm{Pt}$ and $\mathrm{Ag}, L_{\beta}$ for $\mathrm{Pd}$ and $M_{\alpha}$ line for Os and Au. Pure metals were applied as standards for all the PGE except Pt for which synthetic PtAs 2 was emloyed, whereas CoNiAs, native Fe, chalcopyrite, pyrite and $\mathrm{PtAs}_{2}$ were utilized as standards for $\mathrm{Ni}, \mathrm{Fe}, \mathrm{Cu}, \mathrm{S}$ and As, respectively. Representative PGM analyses are listed in Tabs 4-6.

It is known that electron microprobe analysis of PGM is challenging because of the small size of the studied grains, commonly close to the limits for quantitative determination (e.g., Zaccarini et al. 2010; GonzálezJiménez et al. 2011; Kapsiotis et al. 2011). The small size $(\leq 3 \mu \mathrm{m})$ of the discovered PGM in the high-Cr chromitites imposes a certain analytical limitation. The low analytical totals (lower than the theoretical $100 \%$ )

Tab. 3 Concentrations of platinum-group elements and gold in Korydallos chromitites

\begin{tabular}{lcccccccccccc}
\hline Sample & Os (ppb) & Ir (ppb) & Ru (ppb) & Rh (ppb) & Pt (ppb) & Pd (ppb) & Au (ppb) & $\begin{array}{c}\Sigma P G E \\
(\mathrm{ppb})\end{array}$ & $\begin{array}{c}\Sigma \text { PGE }+ \\
\text { Au (ppb) }\end{array}$ & Pd/Ir & Cr\# & Texture \\
\hline K-1 & 17 & 21 & 30 & 3.10 & 31 & 192 & 14.70 & 294.10 & 308.80 & 9.14 & $0.65-0.67$ & $\begin{array}{c}\text { Densely } \\
\text { disseminated }\end{array}$ \\
G-2 & 266 & 364 & 2100 & 1140 & 17100 & 7860 & 488 & 28830 & 29318 & 21.59 & $0.44-0.46$ & Massive \\
\hline
\end{tabular}




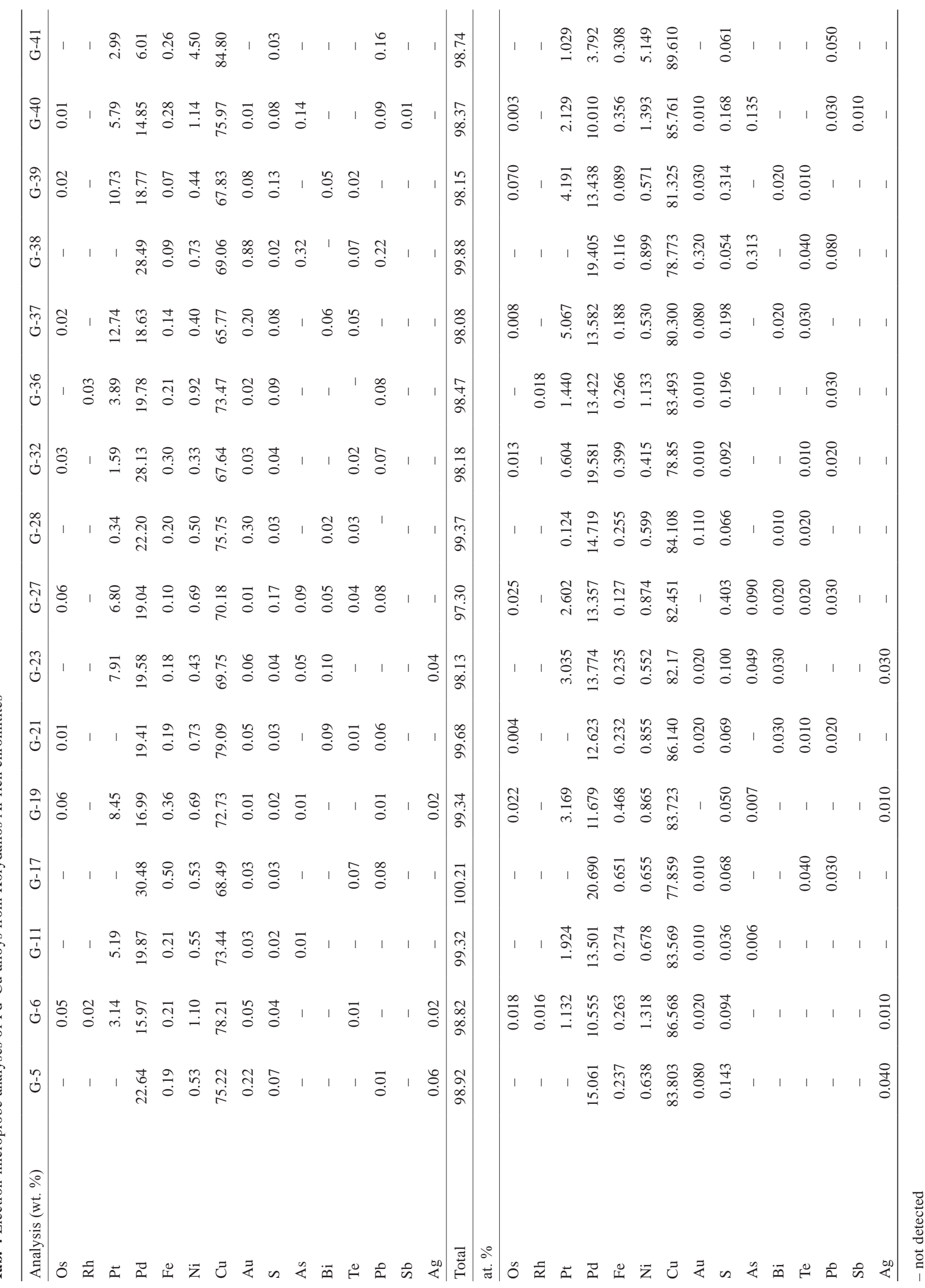




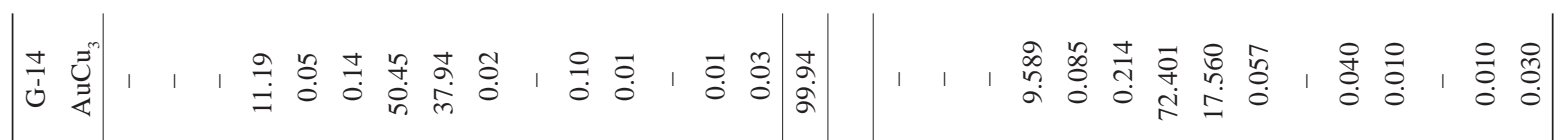

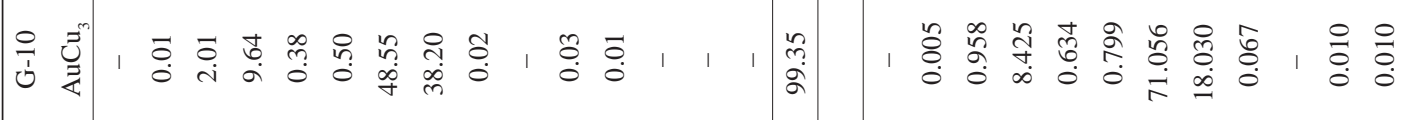

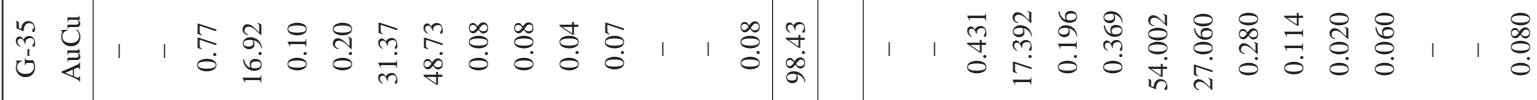

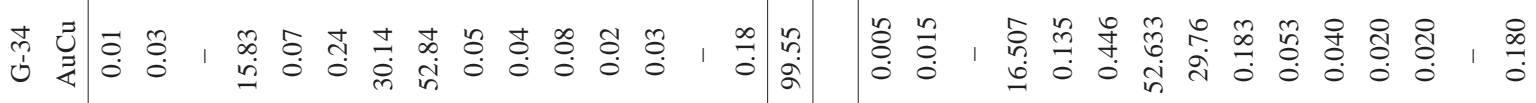

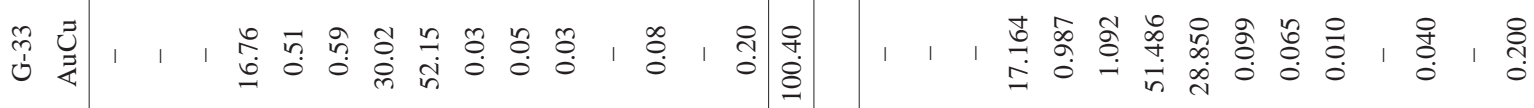

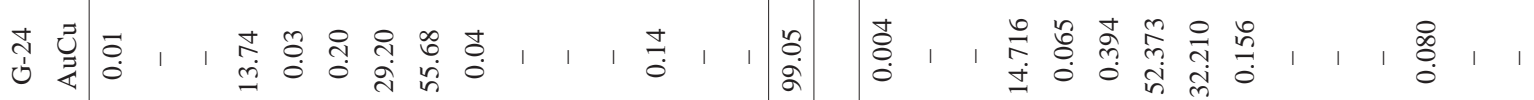

|

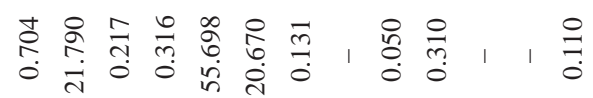

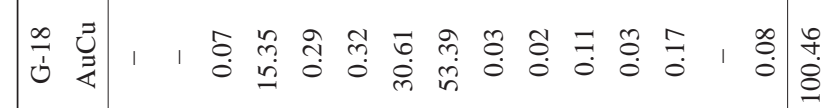

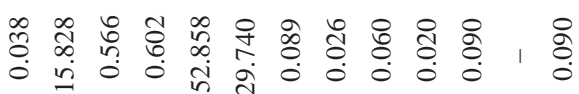

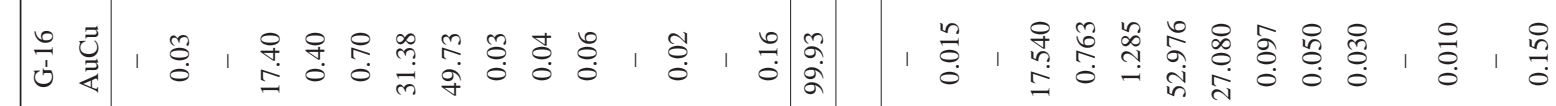

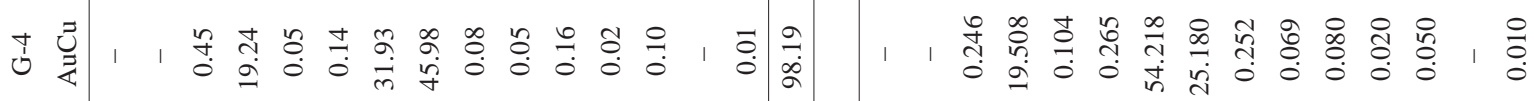

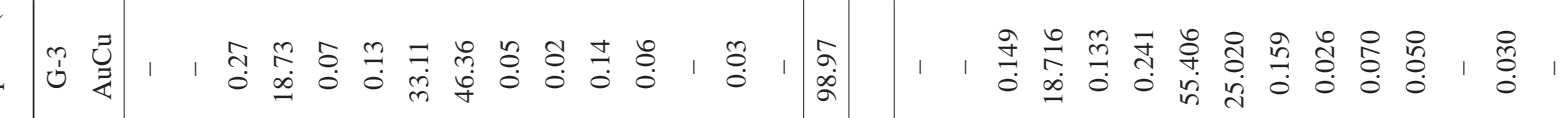

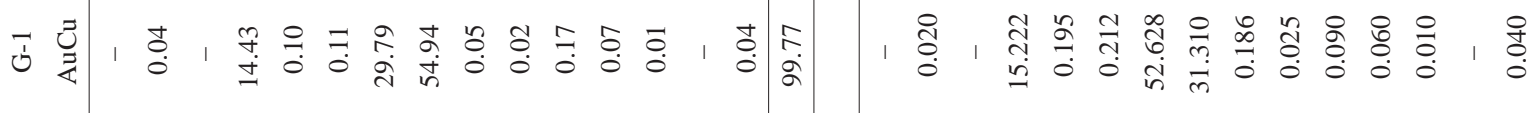


Tab. 6 Electron-microprobe analyses of skaergaardite (Sk), nielsenite (Nls), sperrylite (Sp), zvyagintsevite (Zv) and Pt-Fe-Ni phases from Korydallos Al-rich chromitites

\begin{tabular}{|c|c|c|c|c|c|c|c|c|c|c|}
\hline Analysis (wt. \%) & G-7 & G-13 & G-26 & G-12 & G-30 & G-22 & G-25 & G-29 & G-8 & G-31 \\
\hline Mineral & Sk & $\mathrm{Sk}$ & $\mathrm{Sk}$ & Nls & Nls & $\mathrm{Sp}$ & $\mathrm{Sp}$ & $\mathrm{Sp}$ & $\mathrm{Zv}$ & $\mathrm{Pt}-\mathrm{Fe}-\mathrm{Ni}$ \\
\hline Os & - & - & 0.02 & - & - & 0.04 & 0.03 & 0.01 & - & 0.02 \\
\hline Ir & - & - & 0.01 & - & - & 0.01 & - & - & 0.14 & - \\
\hline $\mathrm{Rh}$ & - & - & - & - & - & 0.07 & 0.05 & 0.20 & - & 0.25 \\
\hline Pt & 0.01 & 4.55 & - & 2.16 & 0.62 & 55.91 & 55.64 & 56.75 & 0.27 & 47.86 \\
\hline $\mathrm{Pd}$ & 53.35 & 54.74 & 60.24 & 32.37 & 30.46 & - & 0.43 & - & 60.82 & 3.27 \\
\hline $\mathrm{Fe}$ & 2.46 & 5.59 & 0.41 & 0.36 & 0.26 & 0.17 & 0.10 & 0.17 & 0.05 & 14.86 \\
\hline $\mathrm{Ni}$ & 0.11 & 0.15 & 0.05 & 0.28 & 0.23 & 0.04 & 0.13 & 0.03 & 0.05 & 25.44 \\
\hline $\mathrm{Cu}$ & 32.97 & 29.64 & 29.28 & 61.05 & 65.97 & - & - & 0.04 & 0.02 & 7.81 \\
\hline $\mathrm{Au}$ & 6.98 & 0.14 & 0.28 & 0.23 & 0.11 & - & - & - & - & 1.06 \\
\hline $\mathrm{S}$ & 0.03 & 0.04 & 0.03 & 0.03 & 0.08 & 0.23 & 0.08 & 0.16 & - & 0.03 \\
\hline As & 1.49 & - & 8.23 & - & 0.08 & 42.78 & 42.44 & 43.12 & 0.03 & 0.04 \\
\hline $\mathrm{Bi}$ & 0.06 & 0.07 & 0.01 & - & 0.01 & - & 0.09 & - & - & - \\
\hline $\mathrm{Te}$ & 1.67 & 3.04 & 0.07 & 2.23 & - & - & 0.02 & 0.05 & 0.02 & 0.07 \\
\hline $\mathrm{Pb}$ & 0.18 & 0.28 & 0.02 & 0.11 & 0.08 & - & - & 0.10 & 37.98 & - \\
\hline $\mathrm{Sb}$ & - & - & - & - & - & 0.02 & 0.08 & 0.03 & - & - \\
\hline $\mathrm{Ag}$ & 0.20 & 0.04 & 0.51 & 0.03 & - & - & - & - & 0.08 & - \\
\hline Total & 99.51 & 98.24 & 99.16 & 98.85 & 97.90 & 99.26 & 99.09 & 100.67 & 99.45 & 100.72 \\
\hline \multicolumn{11}{|l|}{ at. \% } \\
\hline Os & - & - & 0.008 & - & - & 0.024 & 0.018 & 0.008 & - & 0.009 \\
\hline Ir & - & - & 0.005 & - & - & 0.004 & - & - & 0.099 & - \\
\hline $\mathrm{Rh}$ & - & - & - & - & - & 0.083 & 0.056 & 0.226 & - & 0.222 \\
\hline $\mathrm{Pt}$ & 0.004 & 2.056 & - & 0.847 & 0.238 & 32.963 & 33.004 & 33.104 & 0.181 & 22.13 \\
\hline Pd & 44.031 & 45.338 & 49.115 & 23.263 & 21.350 & - & 0.471 & - & 75.187 & 2.772 \\
\hline $\mathrm{Fe}$ & 3.869 & 8.823 & 0.629 & 0.490 & 0.349 & 0.342 & 0.199 & 0.350 & 0.125 & 24.002 \\
\hline $\mathrm{Ni}$ & 0.166 & 0.221 & 0.069 & 0.365 & 0.292 & 0.078 & 0.258 & 0.058 & 0.103 & 39.100 \\
\hline $\mathrm{Cu}$ & 45.57 & 41.113 & 39.979 & 73.476 & 77.438 & - & - & 0.079 & 0.037 & 11.086 \\
\hline $\mathrm{Au}$ & 3.110 & 0.060 & 0.120 & 0.090 & 0.040 & - & - & - & - & 0.490 \\
\hline S & 0.090 & 0.102 & 0.068 & 0.074 & 0.174 & 0.818 & 0.299 & 0.557 & - & 0.096 \\
\hline As & 1.747 & - & 9.531 & - & 0.084 & 65.672 & 65.549 & 65.494 & 0.046 & 0.049 \\
\hline $\mathrm{Bi}$ & 0.020 & 0.030 & - & - & - & - & 0.050 & - & - & - \\
\hline $\mathrm{Te}$ & 1.150 & 2.100 & 0.050 & 1.340 & - & - & 0.020 & 0.040 & 0.020 & 0.050 \\
\hline $\mathrm{Pb}$ & 0.080 & 0.120 & 0.010 & 0.040 & 0.030 & - & - & 0.060 & 24.110 & - \\
\hline $\mathrm{Sb}$ & - & - & - & - & - & 0.020 & 0.080 & 0.030 & - & - \\
\hline $\mathrm{Ag}$ & 0.160 & 0.040 & 0.410 & 0.020 & - & - & - & - & 0.090 & - \\
\hline
\end{tabular}

- not detected

combined with the contamination from the spurious fluorescence emission effect due to direct or secondary excitation from the neighboring minerals, enhance the analytical uncertainty. Alternatively, analysis of sizeable PGM grains $(\geq 5 \mu \mathrm{m})$ in concentrates provides more reliable results for a complete characterization of the PGE-mineralogy (Kapsiotis et al. 2007). Therefore, quantitative analyses presented in this study were carried out merely on PGM from the high-Al chromitite concentrates. On the other hand, only qualitative analyses were undertaken on the in situ discovered PGM in the Cr-rich chromitites, which were either too small $(\leq 3$ $\mu \mathrm{m})$ or too inhomogeneous for quantitative analysis. In particular, variable amounts of $\mathrm{Cr}$ and Fe were detected in the analyses of PGM grains enclosed in magnesiochromite grains from the Cr-rich chromitites, which are ascribed to fluorescence from direct or secondary excitation of the magnesiochromite host. Consequently, the qualitative analytical results have been recalculated subtracting all the $\mathrm{Cr}$ and a proportional amount of $\mathrm{Fe}$, as deduced from the $\mathrm{Cr}$ : $\mathrm{Fe}$ ratio of the adjacent magnesiochromite grains. The recalculated data were used for the qualitative identification of the PGM inclusions found in magnesiochromite. 


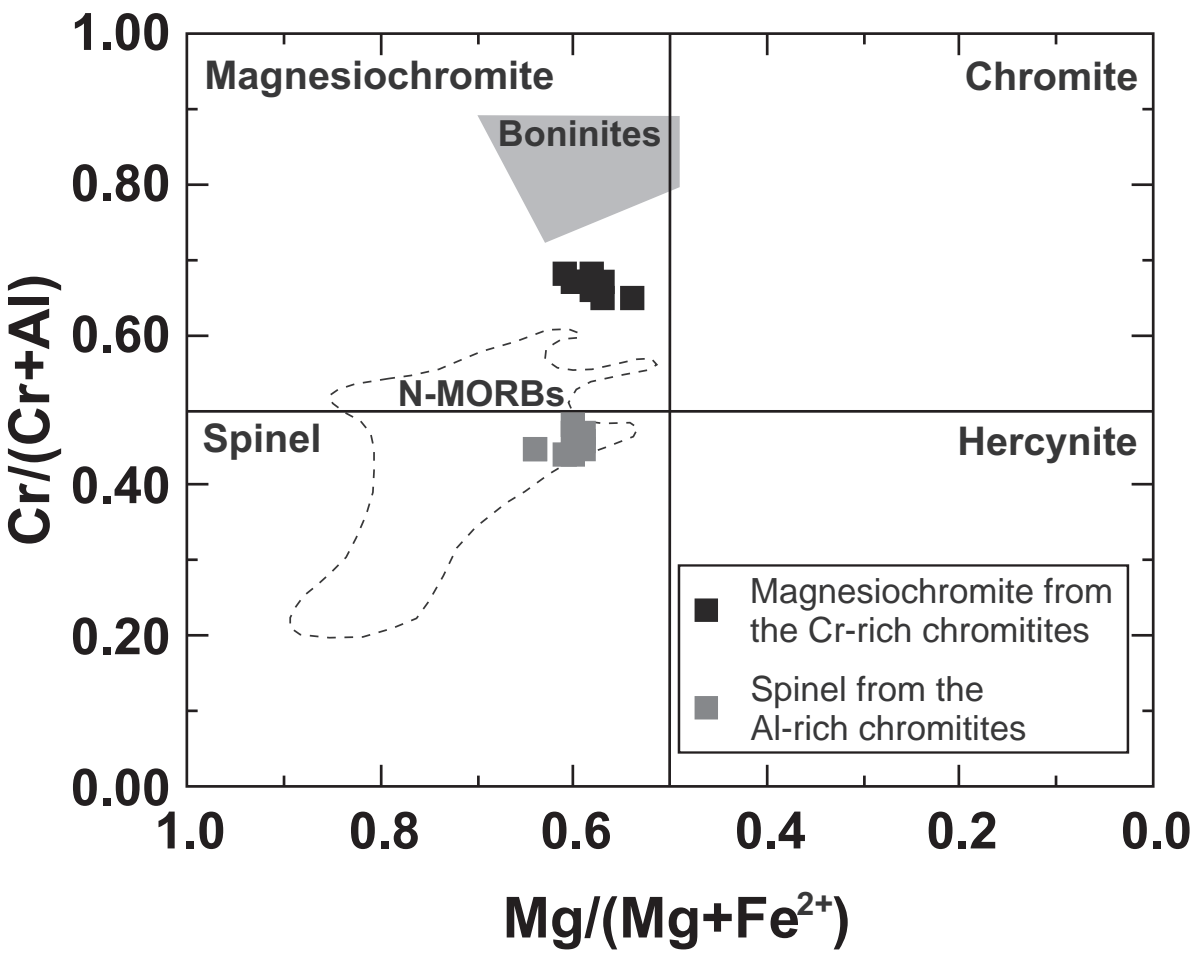

Fig. 3 - Classification and compositional variation of chromian spinel from Korydallos chromitites in terms of $\mathrm{Cr} \#$ $[\mathrm{Cr} /(\mathrm{Cr}+\mathrm{Al})]$ versus $\mathrm{Mg} \#[\mathrm{Mg} /(\mathrm{Mg}+$ $\mathrm{Fe}^{2+}$ )] (fields for spinels in equilibrium with boninites and N-MORBs are after Dick and Bullen 1984).

\section{Chromian spinel chemistry}

Two distinct groups of podiform chromitites are distinguished based on the composition of chromian spinel. A group of relatively high-Cr chromitites contains chromian spinel with chemical composition that varies between 50.77 and 53.35 wt. $\% \mathrm{Cr}_{2} \mathrm{O}_{3}, 16.64$ and 19.30 wt. $\% \mathrm{Al}_{2} \mathrm{O}_{3}, 11.28$ and 12.96 wt. $\% \mathrm{MgO}, 14.89$ and 16.95 wt. \% $\mathrm{FeO}$. The $\mathrm{Cr} \#$ ranges from 0.65 to 0.68 , whereas the $\mathrm{Mg} \#\left[\mathrm{Mg} /\left(\mathrm{Mg}+\mathrm{Fe}^{2+}\right)\right]$ varies between 0.54 and 0.61 (Tab. 1). The other group consists of high-Al chromitites hosting chromian spinel with composition that varies between 37.24 and 39.99 wt. $\% \mathrm{Cr}_{2} \mathrm{O}_{3}, 29.49$ and 32.03 wt. $\% \mathrm{Al}_{2} \mathrm{O}_{3}, 13.15$ and 14.86 wt. $\% \mathrm{MgO}, 14.78$ and 16.72 wt. $\% \mathrm{FeO}$. The $\mathrm{Cr} \#$ ranges between 0.44 and 0.48 and the Mg\# ranges from 0.59 to 0.64 (Tab. 2). The compositional data indicate that chromian spinel is magnesiochromite in the first case and spinel in the second (Fig. 3). The elevated Mg\# of both chromian spinel types $(>0.50)$ is indicative of their unaltered nature (Sobolev and Logvinova 2005). Their $\mathrm{TiO}_{2}$ content is low $(\leq 0.34$ wt. \%), which is typical of ophiolitic chromitites. The analyzed spinel grains plot within the field of chromian spinels in equilibrium with N-MORBs, whereas magnesiochromite analyses fall between the fields of chromian spinels in equilibrium with magmas of N-MORB and boninitic affinity (Fig. 3).

Chromian spinel grains have been locally transformed into porous ferrian chromite along margins and fractures, whereas such alteration patterns are absent in magnesiochromite. The composition of ferrian chromite ranges between 38.90 and 50.46 wt. $\% \mathrm{Cr}_{2} \mathrm{O}_{3}, 4.20$ and 12.63 wt. $\% \mathrm{Al}_{2} \mathrm{O}_{3}, 2.27$ and 16.52 wt. $\% \mathrm{MgO}$, and 21.89 and 39.34 wt. $\% \mathrm{FeO}_{\mathrm{t}}$. Their $\mathrm{SiO}_{2}$ and $\mathrm{MnO}$ content is up to 3.71 wt. $\%$ and 3.50 wt. $\%$, respectively, and is attributed to the introduction of Si and $\mathrm{Mn}$ into spinel lattice during hydrothermal alteration (Burkhard 1993; Barnes 2000). The Cr\# increases from the spinel cores $(0.44-0.48)$ towards the ferrian chromite rims $(0.68-0.86)$. The Fe\# $\left[\mathrm{Fe}^{3+} /\left(\mathrm{Fe}^{3+}+\mathrm{Al}+\mathrm{Cr}\right)\right]$ is variably increased in the altered rims, which indicates that $\mathrm{Fe}^{2+}$ in primary spinel was oxidized to $\mathrm{Fe}^{3+}$ in ferrian chromite.

\section{7. $\mathrm{PGE}+\mathrm{Au}$ concentrations}

The total PGE + Au contents vary significantly between both types of chromitites (Tab. 3). In the Cr-rich chromitite the total PGE grade is relatively low (294.1 ppb), whereas the Au content is even lower (14.7 ppb). These chromitites are enriched in PPGE (especially in Pd) relatively to IPGE, a feature not typically recognized in ophiolitic chromitites (e.g., Proenza et al. 2001; Uysal et al. 2007). They display an almost flat $\mathrm{C} 1$ chondritenormalized PGE-pattern (Fig. 4), particularly from Os to $\mathrm{Pt}$, with a positive slope from $\mathrm{Pt}$ to $\mathrm{Pd}$. The $\mathrm{Pd} / \mathrm{Ir}$ ratio is high (9.14), however the strong positive Pd anomaly can be probably attributed to post-magmatic effects, responsible for the remobilization and the re-concentration of the element. Other studies have reported higher PGE abundances (2099-3871 ppb), a strong enrichment in Pt (1460-3020 ppb) and positively sloped C1 chondrite 


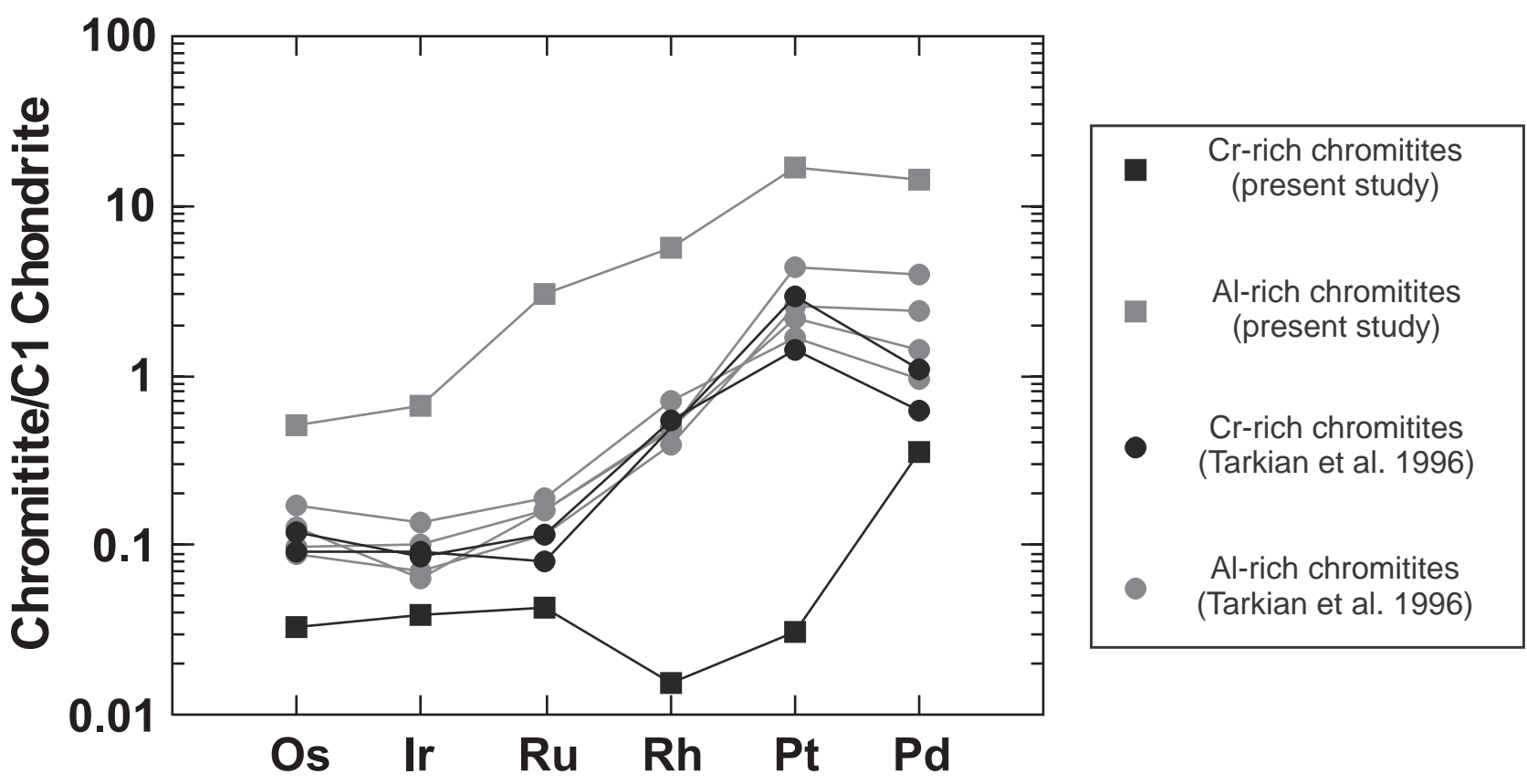

Fig. 4 Chondrite-normalized (Naldrett and Duke 1980) PGE-patterns of the Korydallos chromitites (this study) and those analyzed by Tarkian et al. (1996).

normalized PGE-patterns for these chromitites (Tarkian et al. 1996; Economou-Eliopoulos et al. 1999).

The total PGE grade of the high-Al chromitites is much more elevated (28830 ppb). The Au content is also relatively high (488 ppb). These chromitites consist of spinel accompanied by abundant BMS and BMA and are extremely enriched in PPGE (26100 ppb) with respect to IPGE (2730 ppb). They display a positively sloped $\mathrm{C} 1$ chondrite normalized PGE-pattern (Fig. 4). The Pd/ Ir ratio, probably unaffected by any secondary effects (since there is a strong correlation between the BMS and BMA content of the chromitites and their PGE + Au abundance), is 21.59. Previous studies also reported high-PGE grades (2672-6864 ppb) and positively sloped C1 chondrite-normalized PGE-patterns for the highAl chromitites from Korydallos (Tarkian et al. 1996; Economou-Eliopoulos et al. 1999).

\section{The platinum-group minerals}

\subsection{In situ investigation}

A total of 52 PGM grains have been discovered in 6 out of 10 studied polished thin sections of chromitite. Most of them (48) were found in the high-Cr chromitites. In fact, PGM were discovered in most of the examined polished sections from the high-Cr chromitites (5 out of 6 ) and identification was made based on recalculated qualitative analytical data because of their small size. In particular, the in situ identified PGM in the Cr-rich chromitites comprise inclusions of erlichmanite ( $1 \mu \mathrm{m}$ in the longest dimension), laurite $(2 \mu \mathrm{m})$, sperrylite $(1 \mu \mathrm{m})$, hollingworthite $(3 \mu \mathrm{m})$ and PGE-bearing BMS $(1.5 \mu \mathrm{m})$. Sperrylite (7 grains), laurite (7 grains) and erlichmanite (4 grains) constitute the dominant PGM phases. Common single PGM inclusions in magnesiochromite include hexagonal crystals of laurite (Fig. 5a), sperrylite and erlichmanite. Composite PGM inclusions are intergrowths of erlichmanite with sperrylite and PGE-bearing BMS (Fig. 5b). A few PGM grains including plumbopalladinite $(2 \mu \mathrm{m})$ and palladoarsenide accompanied by Pd-oxide and $(\mathrm{Pd}, \mathrm{Cu})_{16}(\mathrm{Si}, \mathrm{Bi})_{7}$ (probably the bismuthian analogue to vasilite) $(8 \mu \mathrm{m})$, were found in the altered silicate matrix (Fig. 5c). Fractured Pt-Fe (Fig. 5d-e) and Pt-Pd alloys $(<20 \mu \mathrm{m})$, tetraferroplatinum $(4 \mu \mathrm{m})$, Ptbearing arsenides $(3 \mu \mathrm{m})$, laurite (Fig. $5 \mathrm{f})$ and composite crystals of Pd- and Pt-bearing arsenotellurides were found along cracks and microcataclastic zones in magnesiochromite. Pt-bearing and Rh-bearing arsenides $(3 \mu \mathrm{m})$ were also found attached to magnesiochromite grains.

In contrast with the PGE data the in situ examination of the high-Al chromitites yielded only 4 PGM grains discovered in one out of four studied polished sections, which included two skaergaardite crystals $(5 \mu \mathrm{m})$ attached to a BMA grain interstitial to spinel, a grain of $\mathrm{Pt}-\mathrm{Fe}-\mathrm{Ni}$ alloy $(4 \mu \mathrm{m})$ included in ferrian chromite and a $\mathrm{Pd}-\mathrm{Sn}$ grain $(3 \mu \mathrm{m})$ in serpentine.

\subsection{In concentrates investigation}

The study of PGM in polished sections failed to provide the complete picture of the PGM assemblage hosted in the high-Al chromitites. Therefore, PGM were physically 

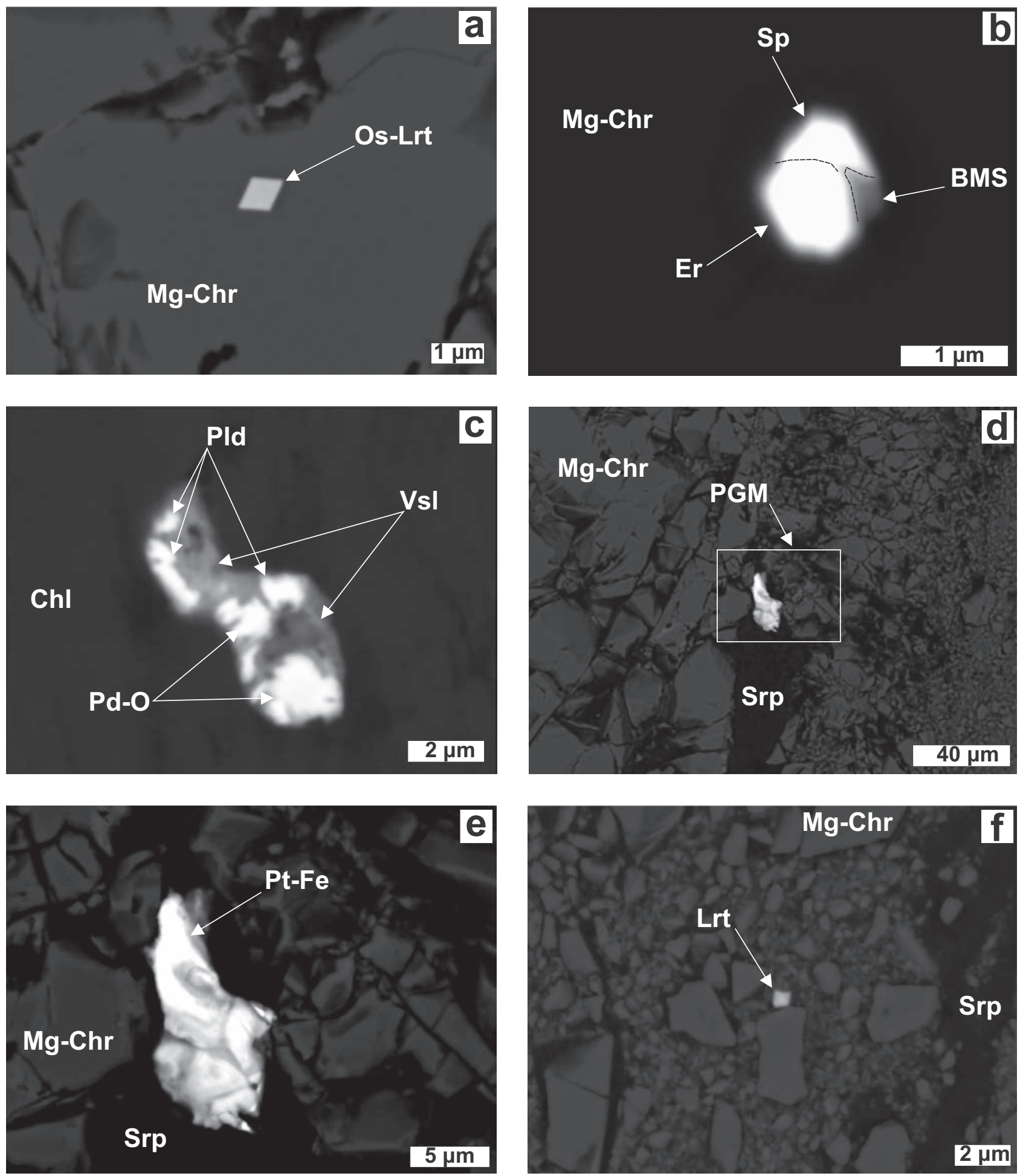

Fig. 5 Back-scattered-electron (BSE) images showing the morphology, texture and mineral assemblage of the discovered PGM in the Cr-rich chromitites of Korydallos. Abbreviations: BMS - base metal sulfide, Chl - chlorite, Er - erlichmanite, Lrt - laurite, Mg-Chr - magnesiochromite, Os-Lrt - Os-bearing laurite, Pld - palladoarsenide, Pd-O - palladium oxide, Sp - sperrylite, Srp - serpentine, Vsl - vasilite.

separated in order to better characterize the PGE-mineralogy in the high-Al chromitites. The study of concentrates showed that the PGM assemblage hosted in the examined chromitites is not in absolute accordance with their PGE contents. Thus the geochemical data should be used with caution, since they are only indicative and not absolutely 
representative of the PGE-mineralogy. The recovered PGM assemblage is characterized by various $\mathrm{Pd}-\mathrm{Cu}$ and $\mathrm{Pd}-\mathrm{Au}-\mathrm{Cu}$ alloy species. The PPGM occur both as single and polyphase grains, forming anhedral to euhedral grains ranging from a few $\mu \mathrm{m}$ up to $95 \mu \mathrm{m}$ in size. Each polymineralic grain commonly consists of two different PPGM phases or a PPGM and a BM phase. The recovered PGM tend to occur in three different textural modes: (i) as single or composite inclusions in BM phases (mainly millerite and awaruite) (Fig. 6a-C) (ii) as attachments on BM minerals (Fig. 6d-e) and finally, (iii) as single or composite crystals not related with any BM mineral (Fig. 6f), some of which might be chemically zoned (Fig. $6 \mathrm{~g}$ ) or corroded (Fig. 6h). The precise textural features of the recovered grains were described in detail by Kapsiotis et al. (2010).

\section{Platinum-group minerals compositions}

\section{1. $\mathrm{Pd}-\mathrm{Cu}$ alloys}

The compositional range for $\mathrm{Pd}-\mathrm{Cu}$ alloys is expressed by the formulae $\mathrm{Cu}_{0.90} \mathrm{Ni}_{0.05} \mathrm{Pd}_{0.04} \mathrm{Pt}_{0.01}$ and $\mathrm{Cu}_{0.77} \mathrm{Pd}_{0.21} \mathrm{Ni}_{0.01} \mathrm{Fe}_{0.01}$. The Pd content of the analyzed $\mathrm{Pd}-\mathrm{Cu}$ alloy crystals varies between 6.01 and 30.48 wt. \%, whereas the concentration of $\mathrm{Cu}$ is higher, ranging from 65.77 to 84.80 wt. \% (Tab. 4). Platinum reaches 12.74 wt. $\%$, whereas Ni varies from 0.33 to 4.50 wt. $\%$. Traces of $\mathrm{Au}$ and $\mathrm{Ni}$ are occasionally present in some $\mathrm{Pd}-\mathrm{Cu}$ alloy crystals. Some of the analyzed unidentified $\mathrm{Pd}-\mathrm{Cu}$ alloys correspond to the chemical formula $\mathrm{PdCu}_{4}$. The $\mathrm{Pd}-\mathrm{Cu}$ alloy analyses plot close to the $\mathrm{Cu}$ apex in the ternary $\mathrm{Pd}-\mathrm{Cu}-\mathrm{Pt}$ diagram (Fig. 7a).

\section{2. $P d$-bearing tetra-auricupride [ideally $(P d, A u) C u]$}

The Au content of Pd-bearing tetra-auricupride ranges between 39.74 and 55.68 wt. \%, whereas the concentration of $\mathrm{Cu}$ varies from 29.20 to 34.54 wt. \% (Tab. 5). Palladium abundances vary between 13.74 and 22.63 wt. \%. Platinum reaches up to 3.15 wt. \%, whereas BM (except for $\mathrm{Cu}$ ) impurities are generally low. The composition of Pd-bearing tetra-auricupride is expressed by the formulae $\left(\mathrm{Au}_{0.32} \mathrm{Pd}_{0.15}\right)_{\Sigma 0.47} \mathrm{Cu}_{0.53}$ and $\left(\mathrm{Au}_{0.25} \mathrm{Pd}_{0.19}\right)_{\Sigma 0.44}$ $\mathrm{Cu}_{0.56}$. Pd-bearing tetra-auricupride contains more Pd and $\mathrm{Cu}$, but less Au compared to the same mineral from the Konder Complex in Russia (Nerkasov et al. 2005). Tetraauricupride was also discovered in magnetite ores from Skyros Island in Greece, but in that case it was depleted in PGE (Tarkian et al. 1992). The atomic proportion of $\mathrm{Pd}$ in Pd-bearing tetra-auricupride is negatively correlated with that of $\mathrm{Au}\left(r^{2}:-0.89\right)$, suggesting that Pd substitutes for $\mathrm{Au}$ in Pd-bearing tetra-auricupride or else that the lat- ter is an intermediate phase between pure skaergaardite and tetra-auricupride. Pd-bearing tetra-auricupride analyses plot close to the ideal $(\mathrm{Pd}, \mathrm{Au}) \mathrm{Cu}$ composition in the ternary $\mathrm{Au}-\mathrm{Cu}-\mathrm{Pd}$ diagram (Fig. 7b).

\section{3. $P d$-bearing auricupride [ideally $\left.(\mathrm{Pd}, \mathrm{Au}) \mathrm{Cu}_{3}\right]$}

Pd-bearing auricupride from Korydallos is slightly depleted in $\mathrm{Cu}$ compared to the ideal composition. Its $\mathrm{Cu}$ content ranges between 48.55 and 50.45 wt. \%, whereas $\mathrm{Au}$ and $\mathrm{Pd}$ vary from 37.94 to $38.20 \mathrm{wt}$. \%, and 9.64 to 11.19 wt. \%, respectively (Tab. 5). The compositional range of Pd-bearing auricupride is given by the formulae $\left(\mathrm{Au}_{0.18} \mathrm{Pd}_{0.08} \mathrm{Pt}_{0.01}\right)_{\Sigma 0.27}$ $\left(\mathrm{Cu}_{0.71} \mathrm{Ni}_{0.01} \mathrm{Fe}_{0.01}\right)_{\Sigma 0.73}$ to $\left(\mathrm{Au}_{0.18} \mathrm{Pd}_{0.10}\right)_{\Sigma 0.28} \mathrm{Cu}_{0.72}$. Pd-bearing auricupride analyses plot close to the ideal ( $\mathrm{Pd}, \mathrm{Au}) \mathrm{Cu}_{3}$ composition in the ternary $\mathrm{Au}-\mathrm{Cu}-\mathrm{Pd}$ diagram (Fig. 7b).

\subsection{Skaergaardite (ideally PdCu)}

The Pd content varies widely in skaergaardite from 53.35 to 60.24 wt. \% (Tab. 6). The concentration of $\mathrm{Cu}$ ranges from 29.28 to 32.97 wt. \%. The compositional variation of Korydallos skaergaardite is expressed by the formulae $\left(\mathrm{Pd}_{0.45} \mathrm{Pt}_{0.02}\right)_{\Sigma 0.47}\left(\mathrm{Cu}_{0.50} \mathrm{Te}_{0.02} \mathrm{Fe}_{0.01}\right)_{\Sigma 0.53}$ and $\mathrm{Pd}_{0.49}\left(\mathrm{Cu}_{0.40} \mathrm{As}_{0.10} \mathrm{Fe}_{0.01}\right)_{\Sigma 0.51}$. The Au content varies from 0.14 to 6.98 wt. \%, whereas $\mathrm{Fe}$ is up to 5.59 wt. \%. $\mathrm{Pt}$ and $\mathrm{Te}$ were also detected in minor amounts, $\leq 4.55 \mathrm{wt}$. $\%$ and 3.04 wt. \%, respectively. One analysis gave elevated concentration of As (8.23 wt. \%). The previous data show that $\mathrm{Pt}$ and $\mathrm{Au}$ substitute for $\mathrm{Pd}$, whereas $\mathrm{Cu}$ is replaced by $\mathrm{As}$, $\mathrm{Fe}$ and Te. Skaergaardite analyses plot close to the ideal $\mathrm{PdCu}$ composition in the ternary $\mathrm{Pd}-\mathrm{Cu}-\mathrm{Pt}$ diagram (Fig. 7c).

\subsection{Nielsenite (ideally $\mathrm{PdCu_{3 }}$ )}

Nielsenite shows a restricted compositional variation, which is expressed by the formulae $\mathrm{Pd}_{0.23} \mathrm{Cu}_{0.77}$ and $\left(\mathrm{Pd}_{0.24} \mathrm{Pt}_{0.01}\right)_{\Sigma 0.25}\left(\mathrm{Cu}_{0.74} \mathrm{Te}_{0.01}\right)_{\Sigma 0.75}$. Nielsenite from Korydallos chromitites contains Pd between 30.46 and 32.37 wt. \%, and $\mathrm{Cu}$ between 61.05-65.97 wt. \% (Tab. 6). Platinum and iron abundances range from 0.62 and 2.16 wt. $\%$, and 0.26 and 0.36 wt. $\%$, respectively. One analysis presents a relatively elevated content of Te. Nielsenite analyses plot close to the ideal $\mathrm{PdCu}_{3}$ composition in the ternary $\mathrm{Pd}-\mathrm{Cu}-\mathrm{Pt}$ diagram (Fig. 7c). Nielsenite analyzed in the present study is richer in Pd and poorer in Pt compared to that analyzed by Prichard et al. (2008a) (Fig. 7c).

\subsection{Sperrylite (ideally PtAs ${ }_{2}$ )}

Sperrylite presents a restricted compositional variation, which is expressed by the chemical formulae $\left(\mathrm{Pt}_{0.99} \mathrm{Pd}_{0.01} \mathrm{Ni}_{0.01} \mathrm{Fe}_{0.01}\right)_{\Sigma 1.02}\left(\mathrm{As}_{1.97} \mathrm{~S}_{0.01}\right)_{\Sigma 1.98}$ and $\left(\mathrm{Pt}_{0.99} \mathrm{Fe}_{0.01}\right)_{\Sigma 1.00}$ 

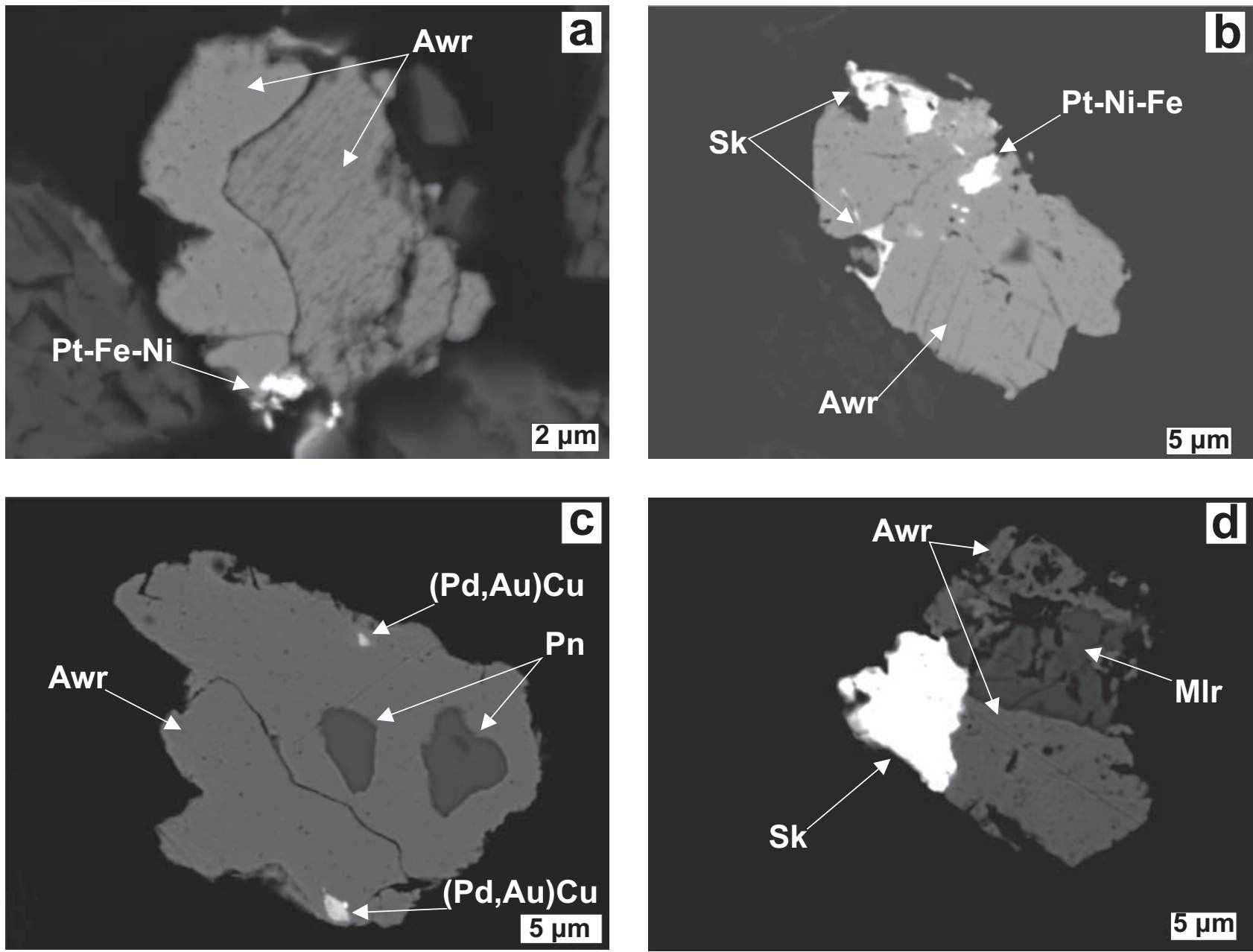

Fig. 6 Back-scattered-electron (BSE) images showing the morphology, texture and mineral assemblage of the recovered PGM from the Al-rich chromitites of Korydallos. Abbreviations: Awr - awaruite, Sk - skaergaardite, Pn - pentlandite, Mlr - millerite, Zv - zvyagintsevite, Cu-Pd palladium-bearing copper-rich alloy, $\mathrm{Pd}-\mathrm{O}$ - palladium oxide.

$\left(\mathrm{As}_{1.98} \mathrm{~S}_{0.02}\right)_{\Sigma 2.00}$. The Pt content of sperrylite varies between 55.64 and 56.75 wt. \%, whereas the As content ranges from 42.44 to 43.12 wt. \% (Tab. 6). Similar sperrylite compositions from Korydallos chromitites were also reported by Prichard et al. (2008a). Traces of Pd, Rh, Os, Ir and BM are also present in the analyzed sperrylite crystals.

\subsection{Zvyagintsevite (ideally $\mathrm{Pd}_{3} \mathrm{~Pb}$ )}

Zvyagintsevite from Korydallos chromitites contains 60.82 wt. \% Pd and 37.98 wt. \% Pb (Tab. 6). It also contains traces of Pt, Ir, Ag, Fe and Ni. Its composition resembles that of zvyagintsevite from Talnakh ore in Siberia (Genkin et al. 1969).

\subsection{Pt-Fe-Ni alloys}

One $\mathrm{Pt}-\mathrm{Ni}-\mathrm{Fe}$ alloy grain was analyzed. It was found to contain elevated concentrations of $\mathrm{Pt}$ (47.86 wt. \%), Ni
(25.44 wt. \%), Fe 14.86 (wt. \%), Cu (7.81 wt. \%) and Pd (3.27 wt. \%) (Tab. 6) which can be expressed by the chemical formula $\mathrm{Pt}_{0.22} \mathrm{Pd}_{0.03} \mathrm{Ni}_{0.40} \mathrm{Fe}_{0.24} \mathrm{Cu}_{0.11}$. The Pt-NiFe alloy analyses reported by Prichard et al. (2008a) were characterized by higher Pt contents.

\section{Discussion}

\subsection{Origin of Korydallos chromitites}

Complicated scenarios involving melt release from diverse magmatic sources at different times during the evolution of the oceanic lithosphere have been proposed to explain the coexistence of two different types of chromitites in the same ophiolite complex (e.g., Melcher et al. 1997; Zhou et al. 1998; Ahmed and Arai 2002; Prichard et al. 2008b). In some cases a vertical distribution with high-Cr chromitites located deeper in the mantle section and high-Al closer to Moho has been observed (Ahmed 

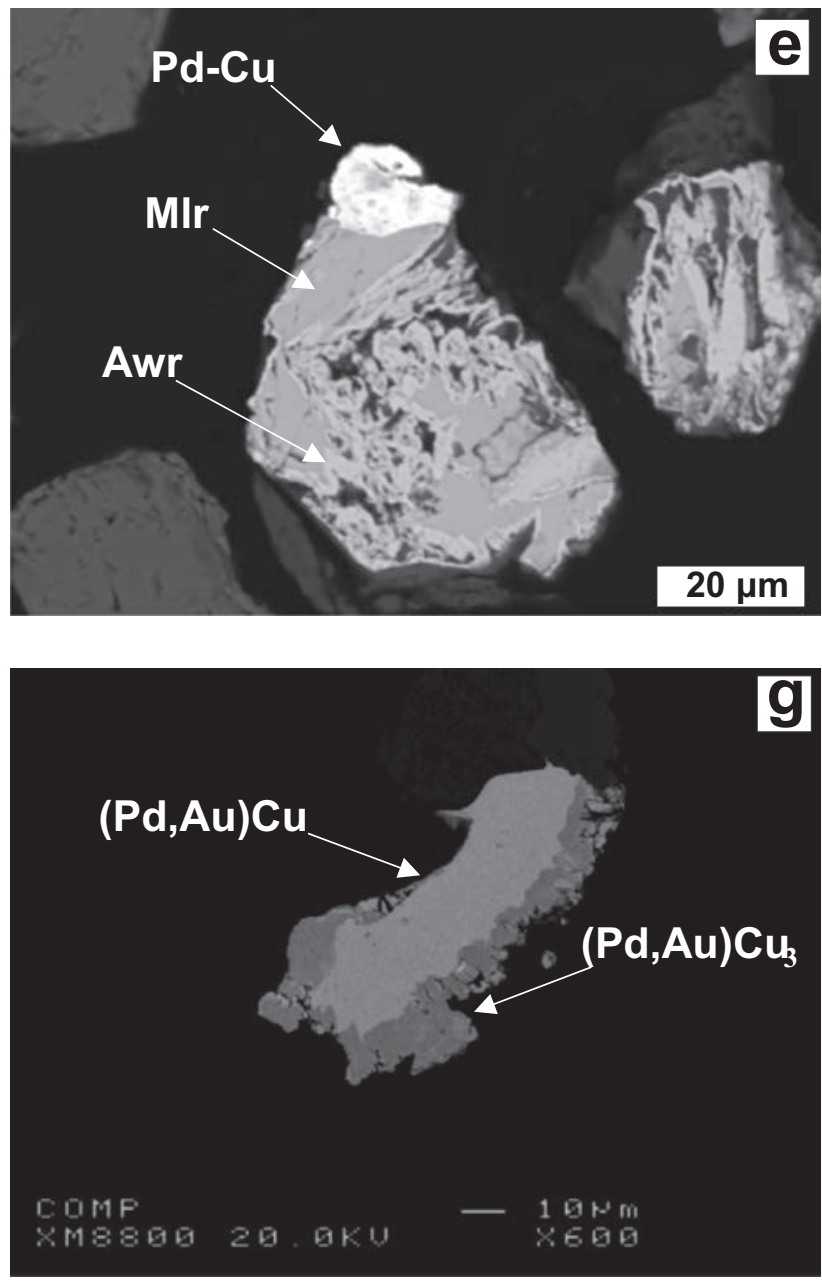

and Arai 2002; Rollinson 2005). Recently GonzálezJiménez et al. (2011) interpreted the coexistence of high$\mathrm{Cr}$ and high-Al chromitites from the Sagua de Tánamo district, Mayarí-Cristal Ophiolitic Massif (eastern Cuba) as reflecting temporal and/or spatial variations of separate melt intrusions, originating from different mantle sources, and emplaced in a geochemically segmented lithosphere across sub-arc mantle domains, during the opening of a back-arc basin in a supra-subduction zone environment.

High $\mathrm{Cr}-\mathrm{Al}$ chromitites coexist within the mantle suite of the Pindos Ophiolite Complex (Economou-Eliopoulos and Vacondios 1995; Tarkian et al. 1996; EconomouEliopoulos et al. 1999). In the Korydallos district, two distinct types of chromitites are found to coexist in a small area. Magnesiochromite compositions from the high-Cr chromitites plot between the fields of chromian spinels in equilibrium with magmas of N-MORB and boninitic affinity. On the other hand, spinel composition from the high-Al chromitites resembles that of chromian spinel in equilibrium with melts of N-MORB affinity. Boninitic melts are produced in the island-arc mantle, whereas hydrous MORB-type melts may be formed in nascent spreading centers, like back-arc basins (e.g.,
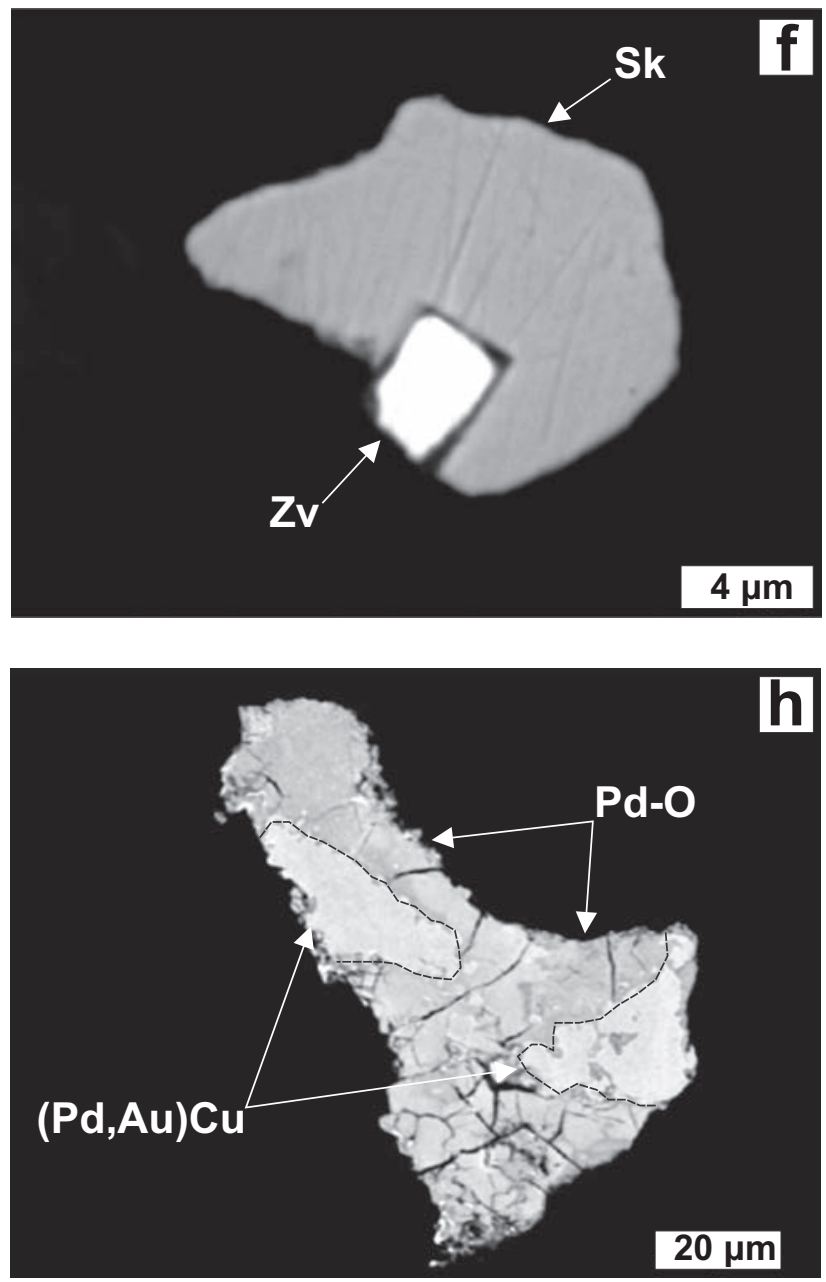

Zhou et al. 1998). So, the formation of the investigated chromitites in different parts of the same mantle wedge above a rapidly developing supra-subduction zone would seem to sufficiently explain their genesis. However, their apparent proximity is in favor of their common magmatic origin. Thus more reasonable would be to suppose that a single parental melt formed the high-Cr chromitites and then moved upwards, more differentiated, to produce the high-Al ones. Such a mechanism can take place in narrow spaces over short time spans (Zaccarini et al. 2011). Moreover, the parental melt must have composition intermediate between boninite and MORB.

In the Pindos Ophiolite Complex are present volcanic rocks covering a wide range of geochemical affinities. Recently, Saccani et al. (2008) suggested that basalts with geochemical features intermediate between MORB and IAT could have been released from the Pindos mantle after an early MORB extraction episode. Furthermore, another study suggested that MORB/IAT magmas in Pindos were produced in a small back-arc basin, as a result of partial melting of a depleted lherzolite hydrated from a downgoing slab (Beccaluva et al. 2005). Consequently it can be claimed that a differentiating MORB/IAT melt 
(a)

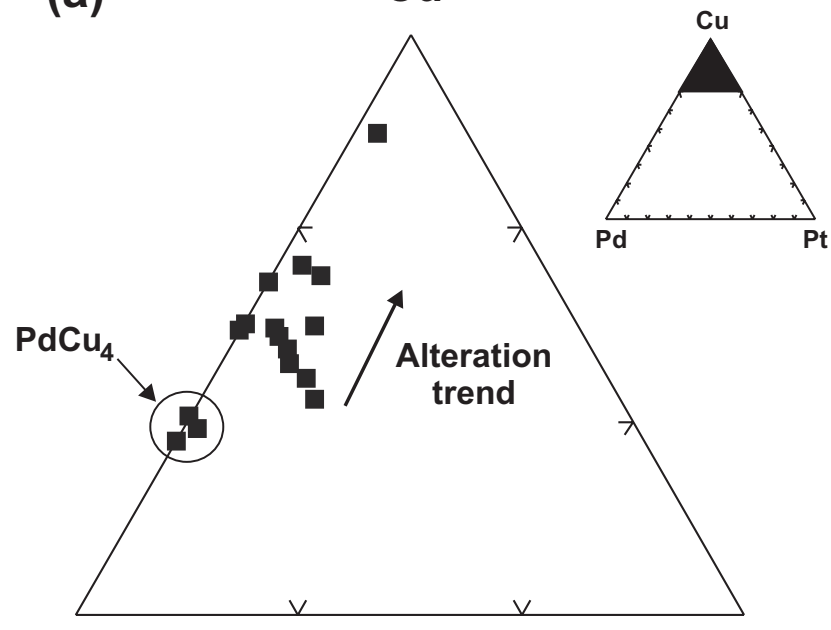

(b)

$\mathrm{Cu}$

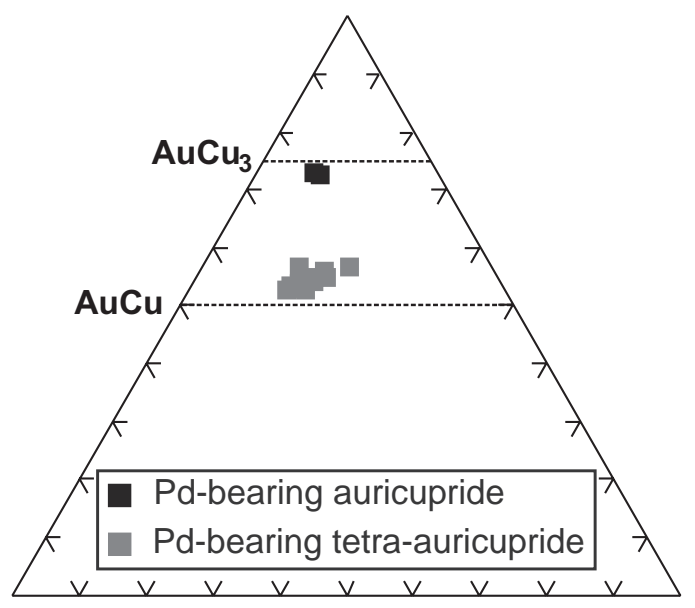

Au
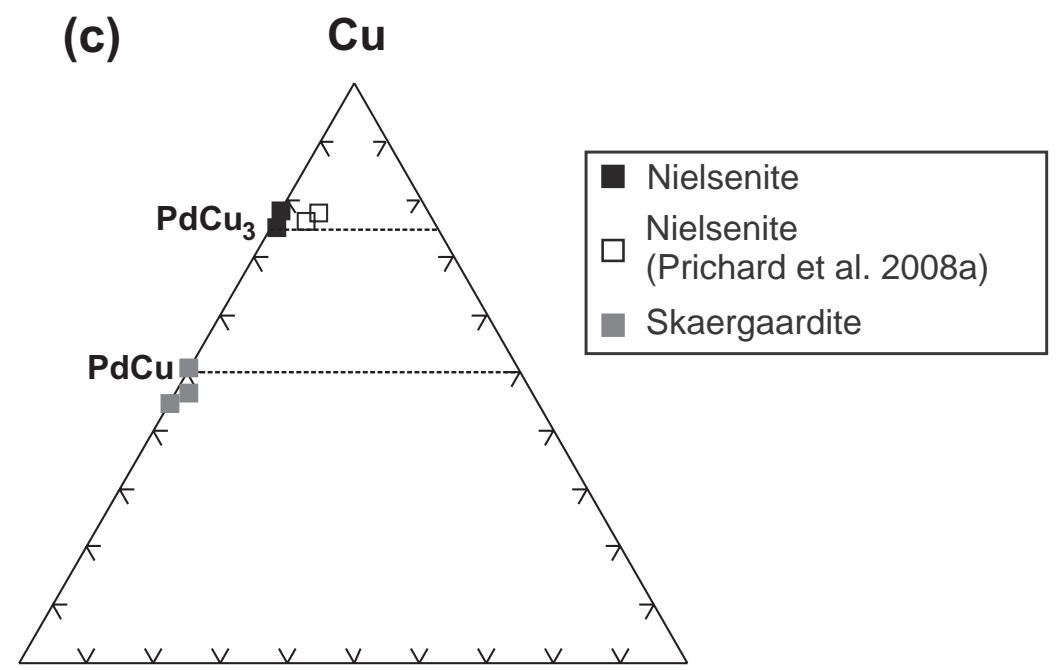

Pd

Pt

Fig. 7a - Compositional variations of $\mathrm{Pd}-\mathrm{Cu}$ alloys in terms of $\mathrm{Pd}-\mathrm{Cu}-\mathrm{Pt}$ (at. \%). The thick arrow indicates a possible alteration trend. $\mathbf{b}-\mathrm{Com}-$ positional variations of $\mathrm{Pd}$-bearing tetra-auricupride and $\mathrm{Pd}$-bearing auricupride in terms of $\mathrm{Au}-\mathrm{Cu}-\mathrm{Pd}($ at. \%). The thick dashed lines represent the compositional variations of ideal $(\mathrm{Pd}, \mathrm{Au}) \mathrm{Cu}$ and $(\mathrm{Pd}, \mathrm{Au}) \mathrm{Cu}_{3} . \mathbf{c}-\mathrm{Compositional} \mathrm{variations} \mathrm{of} \mathrm{skaergaardite} \mathrm{and} \mathrm{nielsenite} \mathrm{in} \mathrm{terms} \mathrm{of} \mathrm{Pd}-\mathrm{Cu}-\mathrm{Pt}$ (at. \%). The thick dashed lines represent the compositional variations of ideal $\mathrm{PdCu}$ and $\mathrm{PdCu}_{3}$.

produced in a small back-arc basin could have been responsible for the formation of Korydallos chromitites.

\subsection{Formation of the chromitites and their PGM assemblages}

Published data indicate that chromitites enriched in PGE may crystallize from melts produced in a critical melting interval of 20-25\% (O'Hara et al. 2001; Prichard et al. 2008b). In addition, PGE enrichment is controlled by the sulfur content of magma (e.g., Cawthorn 1999). According to Keays (1995) differentiating tholeiitic melts, which have formed in a melting interval of $20-25 \%$, may become saturated with sulfur. The PGE-rich nature of the studied chromitites combined with the wide range of $\mathrm{Cr} \#$ of the ore hosted chromian spinel implies that the total degree of melting by which the MORB/IAT melt formed was within the critical melting interval, thus allowing extensive extraction of PGE from the mantle. According to Beccaluva et al. (2005), MORB/IAT magmas in Pindos were produced after 8 to $10 \%$ melting of a depleted lherzolitic to clinopyroxene-bearing harzburgitic source (residue after 10-20\% MORB extraction). 
Subsequently the MORB/IAT melt supposedly upwelled and reacted with the sulfide-poor shallow mantle peridotites to transform them into dunites. Melt-peridotite interaction could have increased the $\mathrm{SiO}_{2}$ content of the resultant melt and mixing with the next pulse of MORB/IAT magma would force the final melt to become saturated in magnesiochromite, thereby leading to the formation of high-Cr chromitites. The lack of IPGE-rich alloys in the studied $\mathrm{Cr}$-rich chromitites combined with the common presence of laurite and erlichmanite, imply that elevated $f S_{2}$ and/or low $T$ conditions had prevailed early in the magmatic system, before magnesiochromite crystallization (e.g., Nakagawa and Franco 1997; Brenan and Andrews 2001; Andrews and Brenan 2002). Moreover, the predominance of sperrylite inclusions in magnesiochromite reveals that, besides $f S_{2}$, $f$ As was also an important intensive variable during the formation of the PGM assemblage. Laurite was the first PGM to precipitate from the melt at relatively high $f S_{2}\left(\log f S_{2}\right.$ : -2 to -1.3$)$ and/or low $T\left(<1200-1300^{\circ} \mathrm{C}\right)$ conditions. Subsequently $\mathrm{fS}_{2}$ approached the $\mathrm{Os}-\mathrm{OsS}_{2}$ buffer and $T$ decreased, thus permitting erlichmanite formation. Experimental estimations showed that sperrylite could be stable at temperatures even higher than $1400^{\circ} \mathrm{C}$ (Berlincourt et al. 1981). However, the crystallization sequence of $\mathrm{Ru}-\mathrm{Os}$ sulfides described above precludes that sperrylite and hollingworthite crystallized at such $T$ conditions. Since laurite is the first PGM to crystallize, it is expected that sulfarsenide and diarsenide formation started below $1200^{\circ} \mathrm{C}$ at elevated fAs. Sperrylite overgrowths on erlichmanite support an idea that diarsenides crystallized after sulfides.

After the formation of the high-Cr chromitites the melt would have moved upwards becoming progressively enriched in $\mathrm{SiO}_{2}$ through melt-peridotite interaction and mixing processes. Enrichment in $\mathrm{SiO}_{2}$ triggered spinel crystallization and sulfur saturation as it is indicated by the abundant BMS and BMA occurring as inclusions in spinel. Sulfur saturation was also enhanced by the removal of $\mathrm{FeO}$ from the magma after spinel precipitation. The high Pd/Ir ratio (21.59) of the Al-rich chromitites is indicative of their formation from an evolved melt. The elevated PGE + Au abundance measured in the Al-rich chromitites is clearly due to their substantial collection by minor amounts of immiscible sulfide melt. In accordance with Prichard et al. (2008a) the present data indicate that $\mathrm{Pt}$ is more commonly alloyed with $\mathrm{Ni}$ and $\mathrm{Fe}$, whereas $\mathrm{Pd}$ is more frequently alloyed with $\mathrm{Cu}$. Additionally, our data suggest that $\mathrm{Au}$ has also a strong tendency to become alloyed with $\mathrm{Cu}$. The BMS and BMA inclusions in spinel imply that the high-Al chromitites formation started at elevated $f S_{2}$ conditions, probably at the $T$ of mss (monosulfide solid solution) formation $\left(1100^{\circ} \mathrm{C}\right)$.
The present data suggest that IPGE were almost completely fractionated into the high-Cr chromitites in the form of discrete IPGM, whereas Pt and Rh were only partially incorporated in the Cr-rich chromitites. On the other hand, Pd and $\mathrm{Au}$ as well as part of $\mathrm{Pt}$ and $\mathrm{Rh}$ were diluted in the residual melt. After Cr-rich chromitite formation, the melt currently depleted in IPGE likely moved upwards. As droplets of immiscible sulfide melt began to co-crystallize with spinel during Al-rich chromitite formation, they could have scavenged the remaining bulk precious metal inventory of the melt. This process is thought to have triggered enrichment of PPGE over IPGE in high-Al chromitites. Such a scenario would also allow nearly complete separation of IPGE from Pd and Au during the differentiation of the chromitite-forming melt.

\subsection{Low-T alteration of PGM}

In the high-Cr chromitites tetraferroplatinum, Pt-Fe and $\mathrm{Pt}-\mathrm{Pd}$ alloys, $\mathrm{Pt}-\mathrm{Ir}-\mathrm{Ni}-\mathrm{As}$ and $\mathrm{Rh}-\mathrm{Ni}-\mathrm{As}$, as well as Pt-bearing arsenotellurides were found associated with secondary silicates. Thus their secondary origin is undisputable. Some fractured secondary alloys were found in microcataclastic zones. A single laurite grain was also observed in a microcataclastic zone. These features support an idea that these PGM did not crystallize from a fluid but they represent alteration products of primary PGM more or less (laurite) susceptible to hydrothermal alteration. Furthermore, the elevated As contents and appreciable amounts of S (qualitative data) measured in some of these phases (Pt-alloys and arsenides and $\mathrm{Rh}$-arsenides) indicate that they represent products of combined de-arsenication and de-sulfurization of primary Pt- and Rh-rich phases like sperrylite and hollingworthite, respectively. Sperrylite and hollingworthite were found only as inclusions in magnesiochromite. However, combined PGE and PGM data show that after magnesiochromite precipitation part of $\mathrm{Pt}$ and $\mathrm{Rh}$ remained in the intercumulus melt, thus probably promoting sperrylite and hollingworthite interstitial crystallization among the magnesiochromite crystals. Composite intergrowths of plumbopalladinite and palladoarsenide accompanied by Pd-oxide and vasilite are interpreted as hydrothermal in origin, representing the result of a strong Pd mobilization as it is also indicated by the geochemical data.

The vast majority of the recovered alloys from the high-Al chromitites of Korydallos is free of elements like $\mathrm{Sb}$ and $\mathrm{Te}$, which are generally interpreted to become introduced in altered phases via secondary processes (Prichard et al. 1994). Thus, the present data indicate that these alloys were originally present in the investigated chromitites and do not represent products of hydrothermal deposition. However, the common textural asso- 
ciation of porous alloys with secondary BMA and BMS indicates that alteration has almost completely removed the sulfur from the BMS precursors, leaving a $\mathrm{Pt}-\mathrm{Pd}-\mathrm{Au}$ and $\mathrm{BM}$ assemblage in accordance with Prichard et al. (2008a). Moreover, some Pd-bearing tetra-auricupride grains are zoned and marginally replaced by Pd-bearing auricupride. A few recovered $\mathrm{Pd}-\mathrm{Cu}$ alloy grains are also zoned. The zoned grains display irregular and corroded margins. The transitions in the zoned crystals are sharp and irregular, which is indicative of the secondary origin of the zoning patterns. Particularly, the zoned crystals of Pd-bearing tetra-auricupride have greater $\mathrm{Pd}, \mathrm{Au}$ and Pt contents in the center than at the edge. These data indicate reaction of the alloy with a hydrothermal fluid that caused mobilization of $\mathrm{Pt}, \mathrm{Pd}$ and $\mathrm{Au}$ on a restricted scale. Theoretical predictions support that Pd, Pt and $\mathrm{Au}$ are soluble in $\mathrm{Cl}^{-}$rich aqueous fluids for $T$ higher than $350^{\circ} \mathrm{C}$ (Wood and Normand 2008), $300^{\circ} \mathrm{C}$ (Wood et al. 2002) and $300^{\circ} \mathrm{C}$ (Romberger 1991), respectively. Such conditions are in accordance with the silicate assemblage of serpentine + tremolite + talc, found in the investigated Al-rich chromitites, as well as the assemblage spinel + ferrian chromite + chromian clinochlore, which are both indicative of low amphibolite-facies metamorphism (Barnes 2000).

The Pt- and Pd-bearing oxides accompanying the $\mathrm{Pt}-\mathrm{Fe}-\mathrm{Ni}$ alloys and Pd-bearing tetra-auricupride, respectively, are also interpreted to be secondary, as it is the case for PGM oxides from elsewhere (e.g., Garuti and Zaccarini 1997; Proenza et al. 2008). In particular, the apparent leaching of $\mathrm{Au}, \mathrm{Pd}$ and Pt from Pd-bearing tetra-auricupride seems to be balanced by hydrothermal addition of oxygen. This suggests that the hydrothermal fluid was locally oxidizing enough to convert the primary PGM into oxides.

\section{Conclusions}

The investigation of the chromitites from Korydallos in the Pindos Ophiolite Complex (Greece) has led to the following conclusions:

1. Podiform chromitites containing chromian spinel with a large range of compositions, from high-Cr to high-Al, occur interspersed within a single peridotite block $(<100 \mathrm{~m}$ long) in the Korydallos mélange.

2. The high-Cr chrome ores host magnesiochromite with high Cr\# (0.65-0.68), whereas the high-Al ones are composed of low Cr\# (0.44-0.48) spinel.

3. The high-Cr chromitites host a primary PGM assemblage mainly dominated by sperrylite, laurite and erlichmanite inclusions in magnesiochromite. The Al-rich chromitites host a PGM assemblage that mainly consists of $\mathrm{Pd}-\mathrm{Cu}$ and $\mathrm{Pd}-\mathrm{Au}-\mathrm{Cu}$ alloys.
4. The high-Cr and high-Al chromitites of Korydallos crystallized from the same progressively differentiating reactive melt of MORB/IAT affinity almost at the same mantle level.

5. PGE-mineralogy data show that the IPGE were fractionated in the Cr-rich chromitites as discrete PGM phases, whereas Pd and Au were concentrated in the BMS-rich high-Al chromitites.

6. The secondary PGM assemblages were formed most likely by the invasion of an oxidizing hydrothermal fluid in the chromitites causing de-sulfurization of the primary PGM.

Acknowledgements. This paper is based in part on the Ph.D. thesis of A. Kapsiotis at the University of Patras, Greece. Drs. F. Zaccarini and I. Uysal are gratefully acknowledged for their constructive criticism and helpful comments on a preliminary version of the manuscript. Dr. R. Skála is thanked for his thorough editorial review, which substantially improved the paper. Special thanks are also due to Drs. V. Janoušek and S. Vrána for their editorial comments, linguistic help and technical assistance in the preparation of the manuscript. The author is thankful to B. Kotsopoulos at the University of Patras for his help with the scanning electron microscope. Research was partly financed by the University of Patras, Karatheodoris Project B097. A. Kapsiotis was also supported by the State Scholarship Foundation of Greece (IKY) during his Ph.D. study.

\section{References}

Ahmed AH, Arai S (2002) Unexpectedly high-PGE chromitite from the deeper mantle section of the northern Oman ophiolite and its tectonic implications. Contrib Mineral Petrol 143: 263-278

Andrews DRA, Brenan JM (2002) Phase-equilibrium constraints on the magmatic origin of laurite and Os-Ir alloy. Canad Mineral 40: 1705-1716

Bacuta GC, Kay RW, GibBS AK, Lipin BR (1990) Platinumgroup element abundance and distribution in chromite deposits of the Acoje Block, Zambales Ophiolite Complex, Philippines. J Geochem Explor 37: 113-145

BARNES SJ (2000) Chromite in komatiites, II. Modification during greenschist to mid-amphibolite facies metamorphism. J Petrol 41: 387-409

Barnes SJ, Naldrett AJ, Gorton MP (1985) The origin of the fractionation of the platinum-group elements in terrestrial magmas. Chem Geol 53: 303-323

Beccaluva L, Coltorti M, Saccani E, Siena F (2005) Magma generation and crustal accretion as evidenced by Supra-subduction ophiolite of the Albanide-Hellenide Subpelagonian Zone. Island Arc 14: 551-563 
Berlincourt LE, Hummel HH, Skinner BJ (1981) Phases and phase relations of the platinum-group elements. In: CABri LJ (ed) Platinum-Group Elements: Mineralogy, Geology, Recovery. Canadian Institute of Mining and Metallurgy 23: 19-45

Brenan JM, Andrews DRA (2001) High-temperature stability of laurite and Ru-Os-Ir alloys and their role in PGE fractionation in mafic magmas. Canad Mineral 39: 341-360

Burgath KP, Mohr M, Bosnjaku B (2003) Unusual lowand high-sulphur Pt and Pd enrichments in ophiolites of the Balkan Peninsula. In: Elıopoulos DG (ed) Mineral Exploration and Sustainable Development. Millpress, Rotterdam, pp 563-566

BURKHARD DJM (1993) Accessory chromium spinels: their coexistence and alteration in serpentinites. Geochim Cosmochim Acta 57: 1297-1306

CAWTHORN RG (1999) The platinum and palladium resources of the Bushveld Complex. S Afr J Sci 95: 481-489

Dick HJB, Bullen T (1984) Chromian spinel as a petrogenetic indicator in abyssal and Alpine-type peridotites and spatially associated lavas. Contrib Mineral Petrol 86: 54-76

Economou-Eliopoulos M, Vacondios I (1995) Geochemistry of chromitites and host rocks from the Pindos Ophiolite Complex, Greece. Chem Geol 122: 99-108

Economou-Eliopoulos M, TARKian M, SAmbanis G (1999) On the geochemistry of chromitites from the Pindos Ophiolite Complex, Greece. Chem Erde 59: 19-31

Escayola M, Garuti G, Zaccarini F, Proenza JA, Bédard JH, VAN StAAL C (2011) Chromitite and platinum-group element mineralization at Middle Arm Brook, Central Advocate Ophiolite Complex, Baie Verte Peninsula, Newfoundland, Canada. Canad Mineral 49: 1523-1547

Fleet ME, Chryssoulis SL, Stone WE, Weisener CG (1993) Partitioning of platinum-group elements and $\mathrm{Au}$ in the $\mathrm{Fe}-\mathrm{Ni}-\mathrm{Cu}-\mathrm{S}$ system: experiments on the fractional crystallization of sulphide melt. Contrib Mineral Petrol 115: 36-44

GARUTI G, ZACCARINI F (1997) In situ alteration of platinumgroup minerals at low temperature: evidence from serpentinized and weathered chromitite of the Vourinos Complex, Greece. Canad Mineral 35: 611-626

Genkin AD, Evstigneeva TL, Troneva NV, Vyalsov LN (1969) Polarite Pd(Pb,Bi), a new mineral from coppernickel sulfide ores. Zap Mineral Obshchest 98: 708-715

Gervilla F, Proenza JA, Frei R, GonzÁlez-Jiménez JM, Garrido CJ, Melgarejo JC, Meibom A, Diaz-Martinez R, LAVAut W (2005) Distribution of platinum-group elements and Os isotopes in chromite ores from MayariBaracoa Ophiolite Belt (eastern Cuba). Contrib Mineral Petrol 150: 589-607

Godel B, Barnes S, Maier W (2007) Platinum-group elements in sulphide minerals, platinum-group minerals, and whole-rocks of the Merensky Reef (Bushveld Complex, South Africa): implications for the formation of the reef. J Petrol 48: 1569-1604

González-Jiménez JM, Proenza JA, Gervilla F, MelgaRejo JC, Blanco-Moreno JA, Ruiz-Sánchez R, Griffin WL (2011) High-Cr and high-Al chromitites from the Sagua de Tánamo district, Mayarí-Cristal Ophiolitic Massif (eastern Cuba): constraints on their origin from mineralogy and geochemistry of chromian spinel and platinum-group elements. Lithos 125: 101-121

JonEs G, RoBERTSON AHF (1991) Tectono-stratigraphy and evolution of the Mesozoic Pindos ophiolite and related units, northwestern Greece. J Geol Soc, London 148: 267-288

Kapsiotis A, Grammatikopoulos TA, Tsikouras B, Hatzipanagiotou K, Zaccarini F, Garuti G (2007) Investigation of platinum-group minerals (PGM) from Pindos and Vourinos chromitites (Greece) using new technology. In: Andrew CJ (ed) Digging Deeper. Proceedings of the $9^{\text {th }}$ Biennial SGA Meeting, Dublin, pp 1599-1602

Kapsiotis A, Grammatikopoulos TA, Tsikouras, HatzipanaGIOTOU K (2010) Platinum-group mineral characterization in concentrates from high-grade PGE Al-rich chromitites of Korydallos area in the Pindos Ophiolite Complex (NW Greece). Resour Geol 60: 178-191

Kapsiotis A, Grammatikopoulos TA, Tsikouras, Hatzipanagiotou K, Zaccarini F, Garuti G (2011) Mineralogy, composition and PGM of chromitites from Pefki, Pindos Ophiolite Complex (NW Greece): evidence for progressively elevated fAs conditions in the upper mantle sequence. Mineral Petrol 101: 129-150

KEAYS RR (1995) The role of komatiitic magmatism and S-saturation in the formation of ore deposits. Lithos 34: 1-18

Kostopoulos DK (1989) Geochemistry, Petrogenesis and Tectonic Setting of the Pindos Ophiolite, NW Greece. Unpublished PhD Thesis, University of Newcastle, UK, pp 1-468

LEBLANC M (1995) Chromite and ultramafic rock compositional zoning through a paleotransform fault, Poum, New Caledonia. Econ Geol 90: 2028-2039

Li C, Barnes SJ, Makovicky E, Rose-Hansen J, Makovicky M (1996) Partitioning of Ni, Cu, Ir, Rh, Pt and Pd between monosulphide solid solution and sulphide liquid: effects of composition and temperature. Geochim Cosmochim Acta 60: 1231-1238

Malitch KN, Melcher F, Mühlhans H (2001) Palladium and gold mineralization in podiform chromitite at Kraubath, Austria. Mineral Petrol 73: 247-277

Melcher F, Grum W, Simon G, Thalhammer TV, Stumpfl EF (1997) Petrogenesis of the ophiolitic giant chromite deposits of Kempirsai, Kazakhstan: a study of solid and fluid inclusions in chromite. J Petrol 38: 1419-1458 
Melcher F, Grum W, Thalhammer TV, Thalhammer OAR (1999) The giant chromite deposit at Kempirsai, Urals: constraints from trace elements (PGE, REE) and isotope data. Miner Depos 34: 250-272

Nakagawa M, Franco HEA (1997) Placer Os-Ir-Ru alloys and sulphides: indicators of sulphur fugacity in an ophiolite? Canad Mineral 35: 1441-1452

NALDRETT AJ (1981) Platinum-group element deposits. Canadian Institute of Mining and Metallurgy 23: 197-232

NALDRETT AJ, Duke JM (1980) Pt metals in magmatic sulfide ores. Science 208: 1417-1424

Nerkasov IY, Lennikov A, Zalishchack BL, Oktyabrsky RA, Ivanov VV, Spain VI, Taskaev VI (2005) Compositional variations in platinum-group minerals and gold, Konder alkaline-ultrabasic Massif, Aldan Shield, Russia. Canad Mineral 43: 637-654

O'Hara MJ, Fry N, Prichard HM (2001) Minor phases as carriers of trace elements in non-modal crystal liquid separation processes, II: Illustrations and bearing on behavior of REE, U, Th and PGE in igneous processes. J Petrol 42: 1887-1910

Ohnenstetter M, Karaj N, Neziraj A, Johan Z, Cina A (1991) Le potential platinifere des ophiolites: mineralizations en elements du groupe du platine (PGE) dans les massifs de Tropoja et Bulqiza, Albania. CR Acad Sci Paris 313: 201-208

Pe-Piper G, Tsikouras B, Hatzipanagiotou K (2004) Evolution of boninites and island-arc tholeiites in the Pindos Ophiolite, Greece. Geol Mag 141: 455-469

Piña R, Gervilla F, Ortega L, Lunar R (2008) Mineralogy and geochemistry of platinum-group elements in the Aguablanca Ni-Cu deposit (SW Spain). Mineral Petrol 92: 259-282

Prichard H, Ixer A, Lord RA, Maynard J, Williams N (1994) Assemblages of platinum-group minerals and sulfides in silicate lithologies and chromite-rich rocks within the Shetland Ophiolite. Canad Mineral 32: 729-746

Prichard H, Economou-Eliopoulos M, Fisher PC (2008a) Contrasting platinum-group mineral assemblages from two different podiform chromitite localities in the Pindos Ophiolite Complex, Greece. Canad Mineral 46: 329-341

Prichard HM, Neary CR, Fisher PC, O’Hara MJ (2008b) PGE-rich podiform chromitites in the Al 'Ays Ophiolite Complex, Saudi Arabia: an example of critical mantle melting to extract and concentrate PGE. Econ Geol 103: 1507-1529

Proenza Ja, Gervilla F, Melgarejo JC, Bodinier JL (1999) Al- and Cr-rich chromitites from the Mayarí-Baracoa Ophiolitic Belt (Eastern Cuba): consequence of interaction between volatile-rich melts and peridotites in suprasubduction mantle. Econ Geol 94: 547-566

Proenza Ja, Gervilla F, Melgarejo JC, Vera O, Alfonso P, FALLiCK A (2001) Genesis of sulfide-rich chromite ores by the interaction between chromitite and pegmatitic olivine- norite dikes in the Potosí Mine (Moa-Baracoa Ophiolitic Massif, eastern Cuba). Miner Depos 36: 658-669

Proenza Ja, Zaccarini F, Escayola M, Cabana C, SchaLAMUK K, Garuti G (2008) Composition and textures of chromite and platinum-group minerals in chromitites of the Western Ophiolitic Belt from Pampean Ranges of Córdoba, Argentina. Ore Geol Rev 33: 32-48

Rassios A, Sмith AG (2000) Constraints on the formation and emplacement age of western Greek ophiolites (Vourinos, Pindos and Othris) inferred from deformation structures in peridotites. In: Dilex Y, Moores EM, Elthon D, Nicolas A (eds) Ophiolites and Ocean Crust: New Insights from Field Studies and the Ocean Drilling Program. Geological Society of America Special Papers 349: 473-483

Reimer L (1998) Scanning Electron Microscopy: Physics of Image Formation and Microanalysis. Springer, Berlin, pp 1-515

RolLinson H (2005) Chromite in the mantle section of the Oman ophiolite: a new genetic model. Island Arc 14: 542-550

RoMBERGER SB (1991) Transport and deposition of precious metals in epithermal deposits. In: RAINES GL, LisLe RE, Richard E, Schafer RW, WiLkinson WH (eds) Geology and Ore deposits of the Great Basin, Nevada. Symposium Proceedings of the Geological Society of Nevada, Reno, Nevada, pp 219-232

Saccani E, Photiades A, Beccaluva L (2008) Petrogenesis and tectonic significance of Jurassic IAT magma types in the Hellenide ophiolites as deduced from the Rhodiani ophiolites (Pelagonian Zone, Greece). Lithos 104: 71-84

Sobolev NV, Logvinova AM (2005) Significance of accessory chrome spinel in identifying serpentinite paragenesis. Int Geol Rev 47: 58-64

Spray JG, RodDick JC (1980) Petrology and ${ }^{40} \mathrm{Ar} /{ }^{39} \mathrm{Ar}$ geochronology of some Hellenic sub-ophiolite metamorphic rocks. Contrib Mineral Petrol 72: 43-55

Tarkian M, Economou-Eliopoulos M, Economou DG (1992) Platinum-group minerals and tetraauricupride in ophiolitic rocks of Skyros Island, Greece. Mineral Petrol 47: 55-66

Tarkian M, Economou-Eliopoulos M, Sambanis G (1996) Platinum-group minerals in chromitites from the Pindos Ophiolite Complex, Greece. Neu Jb Mineral, Mh 4: 145-160

Uysal I, Tarkian M, Sadiklar MB, Sen C (2007) Platinumgroup element geochemistry and mineralogy of ophiolitic chromitites from the Kop Mountains, Northeastern Turkey. Canad Mineral 45: 355-377

WhITECHURCH H, PARROT JF (1978) Ecailles métamorphiques infra peridotiques dans le Pinde septentrional (Grèce): croûte oceanique, métamorphisme et subduction. CR Acad Sci Paris 286: 1491-1494 
Wood SA (2002) The aqueous geochemistry of the platinum-group elements with applications to ore deposits. In: CABRi LJ (ed) The Geology, Mineralogy and Mineral Beneficiation of Platinum-Group Elements. Canadian Institute of Mining and Metallurgy 54: 211-249

Wood SA, Normand C (2008) Mobility of palladium chlorite complexes in mafic rocks: insights from a flowthrough experiment at $25^{\circ} \mathrm{C}$ using air-saturated, acidic, and Cl-rich solutions. Mineral Petrol 92: 81-97

Zaccarini F, Bakker RJ, Garuti G, Aiglsperger T, Thalhammer OAR, Campos L, Proenza JA, Lewis JF (2010) Platinum group minerals in chromitite bodies of the Santa
Elena Nappe, Costa Rica: mineralogical characterization by electron microprobe and Raman-spectroscopy. Bul Soc Geol Mex 62: 161-171

Zaccarini F, Garuti G, Proenza JA, Campos L, Thalhammer OAR, Aiglsperger T, Lewis J (2011) Chromite and platinum-group-elements mineralization in the Santa Elena ophiolitic ultramafic nappe (Costa Rica): geodynamic implications. Geol Acta 9: 407-423

Zhou M-F, Sun M, Keays RR, Kerrich RW (1998) Controls on platinum-group elemental distributions of podiform chromitites: a case study of high-Cr and high-Al chromitites from Chinese orogenic belts. Geochim Cosmochim Acta 62: 677-688 
